\title{
Does Asia's choice of exchange rate regime affect Europe's exposure to US shocks?
}

\author{
Bojan Markovic and Laura Povoledo ${ }^{1}$
}

\begin{abstract}
In this paper we use a stylised three-country model to analyse how the transmission of US shocks to Europe might be affected by Asia's choice of exchange rate regime. We find that if Asia pegs its exchange rate to the dollar, the impact of US shocks on European output and inflation is likely to be bigger than it otherwise would have been. This happens because, without nominal exchange rate flexibility, Asian firms react to the shocks originating in the United States by implementing significant price adjustments, which in turn affect Europe's relative competitive position. On the theoretical side, our results contribute to the literature by suggesting that the shock insulation property of floating exchange rates extends beyond the two countries that have currencies that are free to move. The transmission of shocks between two countries can also be dampened by the choice of floating exchange rates in a third country. On the practical side, our results suggest that, if China did eventually decide to float its currency, Europe's exposure to US shocks would decrease.
\end{abstract}

\section{INTRODUCTION}

$\mathrm{T}$ HE INTERNATIONAL ECONOMIC ENVIRONMENT has been dramatically transformed in recent years by increasing global financial integration and by the rapid growth of several Asian economies. Both events profoundly affect macroeconomic interdependence. For example, as China considers whether or not to allow the renminbi to float, 2 many commentators have asked what the consequences of this decision will be for other countries in the world economy. In other words, both economic commentators and policymakers recognise that the configuration of the international monetary system (which is determined by exchange rate arrangements) affects the international transmission of shocks.

At a broad level of simplification, one could characterise the international monetary system as consisting of three large blocs: the euro, the US dol- 
lar, and a bloc of Asian currencies that have been fixed (to varying degrees) against the dollar. ${ }^{3}$ Given the size of the Asian bloc, the choice of exchange rate regime in Asia may affect the transmission of shocks between the United States and the euro bloc. This is because any US shock triggers an immediate reaction from the Asian central banks if the latter are pegging their currencies, ${ }^{4}$ whereas if their exchange rates are floating then Asian central banks do not necessarily need to take action.

The purpose of this paper is to analyse how Europe's output and inflation respond to shocks originating in the United States, and compare two cases: (1) when Asia pegs its currency to the dollar, and (2) when the Asian currency freely floats. We choose to investigate the transmission of US shocks to Europe because the empirical literature has found that Europe is more affected by US shocks than vice versa (Artis et al 2006). To conduct our analysis we use a three-country model that parallels the centre-periphery model of Corsetti et al (2000), which we extend by adding a non-traded goods sector in each country, by introducing more complex dynamics, and by adding exogenous supply and demand shocks.

At least since Friedman's (1953) pioneering contribution, 5 there has been a vigorous debate on the impact of exchange rate regimes on the international transmission of shocks. We aim to contribute to this debate an entirely different perspective. Rather than analysing how the choice of exchange rate regime in one country affects its exposure to foreign shocks, we analyse how the transmission of shocks between two countries is affected by the choice of the exchange rate regime in a third country.

To our knowledge, there are no other papers that analyse this issue directly although some studies have, in a more indirect manner, looked into it. For example, using a three-country model, Obstfeld and Rogoff (2005) show that, in the event of an unspecified shock that balances the US current account, the euro area effective (trade-weighted) real exchange rate would appreciate more if Asia kept its exchange rate pegged to the dollar, than if Asia decided to float. 6 Our aim is to expand their analysis in a number of ways: (1) by using a dynamic setting, (2) by specifying the nature of the shocks, and (3) by looking at the effects of the regime choice on other variables.

The three-country model in this paper has imperfectly substitutable consumption goods, a traded and a non-traded 7 goods sector in each country, nominal rigidities, and a monetary policy authority. We consider only supply (productivity) and demand (consumption preference) shocks originating in the United States. Using both impulse responses and variance decompositions, we examine the transmission of these shocks to Europe under two scenarios: when Asia pegs its currency to the dollar, and when the Asian currency freely floats.

Our main result is as follows. If Asia keeps its exchange rate pegged to the dollar, both output and inflation in Europe respond more to US shocks. This happens because, in the absence of nominal exchange rate adjustments, 
Asian firms react to the US shocks by implementing large price changes that strongly affect Europe's relative competitive position. Importantly, the impulse responses show that the adjustment of Asian prices is especially pronounced after a shock occurring in the US non-traded goods sector. This particular finding contributes to the robustness of our main result to changes in parameter values.

Asia's adoption of a fixed peg vis-à-vis the dollar has two other important effects. First, if the Asian currency is pegged to the dollar, the nominal interest rate in Asia must move in line with the US nominal interest rate. Second, US shocks do not only affect the euro-dollar bilateral exchange rate, but they also affect the exchange rate of the euro vis-à-vis the Asian currency. Both effects influence the responses of Europe's output to US shocks. Nevertheless, our general equilibrium model shows that the above-mentioned larger adjustment in Asian prices, induced by the peg in Asia, dominates the other effects.

The rest of the paper is organised in the following way. Section 2 presents the model, while Section 3 discusses the calibration of the parameter values. Section 4 analyses the transmission of each US shock to Europe, and Section 5 examines the impact of Asia's choice of exchange rate regime on Europe's exposure to US shocks. Section 6 conducts sensitivity and robustness checks. Finally, Section 7 concludes.

\section{THE MODEL}

To conduct our analysis we use a dynamic stochastic general equilibrium model with nominal rigidities. It consists of three countries or regions, namely Europe $(E)$, the United States $(U)$ and Asia $(A)$. We assume that Europe has size $\gamma_{E} \gamma_{P}$, the United States has size $\gamma_{P}-\gamma_{E} \gamma_{P}$, and Asia has size $1-\gamma_{P} .8$ The agents in the economy are households, firms, and governments. Households in each country consume a variety of differentiated goods, each produced by a single monopolistic firm. Each firm produces only one good, which can be either traded or non-traded. In each country, a continuum of traded and a continuum of non-traded varieties are produced. The size ${ }^{9}$ of the traded and the non-traded goods sectors in each country is constant.

Goods are imperfect substitutes in consumption. Households in each country first allocate their expenditure between traded and non-traded goods, and then they allocate their expenditure between traded goods of different countries. Finally, households allocate their expenditure among all the traded and the non-traded individual goods varieties.

Nominal rigidities are modelled by assuming that firms pay a nonlinear adjustment cost whenever they change their prices, as in Ireland (2001); moreover, prices are sticky in the producer's currency.10 We consider only supply (productivity) and demand shocks. ${ }^{11}$ 


\subsection{Households}

Households derive utility from an index of consumption goods $(C)$, real money balances $(M / P)$ and leisure $(1-H)$. The representative household in country $j(j=E, U$ or $A)$ has the following lifetime utility function:

$$
U_{0}^{j}=E_{t} \sum_{t=0}^{\infty} \beta^{t}\left[\omega_{t}^{j} \frac{\left(C_{t}^{j}\right)^{1-\xi_{C}}}{1-\xi_{C}}+\frac{\chi}{1-\xi_{M}}\left(\frac{M_{t}^{j}}{P_{t}^{j}}\right)^{1-\xi_{M}}+\varphi \frac{\left(1-H_{t}^{j}\right)^{1-\xi_{H}}}{1-\xi_{H}}\right]
$$

where $\beta$ is the discount factor and $\omega^{j}$ is a country-specific exogenous stochastic process that affects consumption preferences. We interpret a shock to this process as a 'demand' shock. It is modelled in the same way as in Neiss and Nelson (2003). ${ }^{12}$ The parameters $\xi_{C}, \xi_{M}, \xi_{H}, \chi$ and $\varphi$ are positive and assumed to be equal in all countries. We also assume that labour can freely move across sectors, and households can contemporaneously supply their labour to the traded and non-traded goods sectors. Total hours worked $H$ are given by the sum of hours worked in both the traded $(T)$ and non-traded $(N)$ goods sectors:

$$
H_{t}^{j}=H_{T, t}^{j}+H_{N, t}^{j}
$$

where $H_{T}^{j}=\int H_{T}^{j}\left(z_{T}^{j}\right) d z_{T}^{j}$ and $H_{N}^{j}=\int H_{N}^{j}\left(z_{N}^{j}\right) d z_{N}^{j}$ are aggregates across firms in each sector. 13 Households can smooth their consumption by buying or selling the domestic and the foreign non-state-contingent nominal bonds. They can also hold money $(M)$, but cannot invest in physical capital. We also introduce a small quadratic cost of holding bonds, 14 which ensures stationarity of the model and a well-defined steady state. 15 The budget constraint of the representative household in country $j$ at date $t$ is:

$$
\begin{aligned}
& \frac{B_{E, t}^{j}}{P_{t}^{j}} \frac{\varepsilon_{t}^{j}}{\varepsilon_{t}^{E}}+\frac{\eta}{2}\left(\frac{B_{E, t}^{j}}{P_{t}^{j}} \frac{\varepsilon_{t}^{j}}{\varepsilon_{t}^{E}}\right)^{2}+\frac{B_{U t}^{j}}{P_{t}^{j}} \frac{\varepsilon_{t}^{j}}{\varepsilon_{t}^{U}}+\frac{\eta}{2}\left(\frac{B_{U t}^{j}}{P_{t}^{j}} \frac{\varepsilon_{t}^{j}}{\varepsilon_{t}^{U}}\right)^{2}+\frac{B_{A, t}^{j}}{P_{t}^{j}} \varepsilon^{j}+\frac{\eta}{2}\left(\frac{B_{A t}^{j}}{P_{t}^{j}} \varepsilon^{j}\right)^{2}+\frac{M_{t}^{j}}{P_{t}^{j}}+C_{t}^{j}-\frac{T_{t}^{j}}{P_{t}^{j}} \\
= & \left(1+i_{t-1}^{\varepsilon}\right) \frac{B_{E, t-1}^{j}}{P_{t}^{j}} \frac{\varepsilon_{t}^{j}}{\varepsilon_{t}^{E}}+\left(1+i_{t-1}^{U}\right) \frac{B_{U t-1}^{j}}{P_{t}^{j}} \frac{\varepsilon_{t}^{j}}{\varepsilon_{t}^{U}}+\left(1+i_{-1}^{A}\right) \frac{B_{A, t-1}^{j}}{P_{t}^{j}} \varepsilon_{t}^{j}+\frac{M_{t-1}^{j}}{P_{t}^{j}}+H_{t}^{j} W_{t}^{j}+\Pi_{T t}^{j}+\Pi_{N}^{j}+R_{t}^{j}
\end{aligned}
$$

where $B_{E}^{j}, B_{U}^{j}$ and $B_{A}^{j}$ denote the holdings of country $E, U$ and $A$ 's nominal bonds (all denominated in the issuer's currency), which pay a rate of interest $i^{E}, i^{U}$ and $i^{A}$ respectively. Bonds are in zero net supply worldwide. The parameter $\eta$ governs the size of the cost of holding bonds. The variable $P^{j}$ is the aggregate price level in country $j$, and $\varepsilon^{j}$ is the price of country $j$ 's currency in terms of country $A$ 's currency (therefore $\varepsilon^{A}=1$ ). Lump-sum government transfers are denoted with $T j, W^{j}$ is the hourly wage rate (equal in both sectors), 
$\Pi_{T}^{j}$ and $\Pi_{N}^{j}$ denote real profits from the ownership of firms in the two sectors, and $R^{j}$ are lump-sum rebates.

Consumers in each country have preferences over domestic and foreign traded goods, and also non-traded goods. Preferences over goods are described by CES aggregators. The consumption index $C j$ in each country $j$ is given by:

$$
C_{t}^{j}=\left[\alpha^{\frac{1}{\mu}}\left(C_{T,}^{j}\right)^{\frac{\mu-1}{\mu}}+(1-\alpha)^{\frac{1}{\mu}}\left(C_{N_{t}}^{j}\right)^{\frac{\mu-1}{\mu}}\right]^{\frac{\mu}{\mu-1}}
$$

where $C_{T}^{j}$ and $C_{N}^{j}$ are consumption sub-indices that represent, respectively, the total consumption of traded and non-traded goods, and $\alpha$ is the weight of traded in total goods. Households in each country first allocate their expenditure on traded goods between country $A$ 's goods and the bundle formed by $E$ and $U$ goods, which together make up the periphery $(P), 17$ then between $E$ and $U$ traded goods:

$$
\begin{gathered}
C_{T, t}^{j}=\left\{\left(\gamma_{p}\right)^{\frac{1}{\rho}}\left(C_{P, T, t}^{j}\right)^{\frac{\rho-1}{\rho}}+\left[\left(1-\gamma_{p}\right) h^{A}\right]^{\frac{1}{\rho}}\left(C_{A, T, t}^{j}\right)^{\frac{\rho-1}{\rho}}\right\}^{\frac{\rho-1}{\rho}} \text { for } j=E, U: h^{A}=1 \\
C_{P, T, t}^{j}=\left\{\left[\left(\gamma_{E}\right) h^{E}\right]^{\frac{1}{\psi}}\left(C_{E, t}^{j}\right)^{\frac{\psi-1}{\psi}}+\left[\left(1-\gamma_{E}\right) h^{U}\right]^{\frac{1}{\psi}}\left(C_{U T, t}^{j}\right)^{\frac{\psi-1}{\psi}}\right]^{\frac{\psi-1}{\psi}} \\
\text { for } j=U, A: h^{E}=1 . \text { For } j=E, A: h^{U}=1
\end{gathered}
$$

The elasticities of substitution $\mu$ (between $T$ and $N$ goods), $\rho$ (between $A$ and $P$ traded goods), and $\psi$ (between $E$ and $U$ traded goods), and the weights $\alpha, \gamma_{P}$ and $\gamma_{E}$ are the same for all countries. The parameters $h^{E}, h^{U}$ and $h^{A}$ are free and allow us to introduce home bias in consumption. ${ }^{18}$

The consumption sub-indices for the individual varieties are given by similar CES aggregators, with the same elasticity of substitution $\theta$ for the traded and non-traded goods sectors in all countries. A higher $\theta$ implies higher substitutability among individual varieties. Therefore $\theta$ is inversely related to the degree of monopolistic competition in the goods market.

Let $P^{j}, P_{N}^{j}, P_{T}^{j}, P_{P T}^{j}, P_{E T}^{j}, P_{U T}^{j}$ and $P_{A T}^{j}$ denote the price indices that match up the consumption aggregators illustrated above. The price indices are defined as the minimal expenditures needed to buy one unit of corresponding consumption bundles - they are obtained in the standard way from the household's preferences. 


\subsection{Firms}

Each firm is a monopolistic supplier of a single differentiated product, which is produced using labour as the only input. The firms' production function is affected by an exogenous stochastic process, common to all firms in the same sector and country. Since we abstract from physical capital, and regard it as fixed in the short run, we assume that the marginal productivity of labour is decreasing. 19

The production functions of the individual firms $z_{T}^{j}$ and $z_{N}^{j}$ operating in the traded and non-traded goods sector in country $j$ at date $t$ are given by:

$$
\begin{gathered}
\tilde{Y}_{T, t}^{j}\left(z_{T}^{j}\right)=A_{T, t}^{j}\left[H_{T, t}^{j}\left(z_{T}^{j}\right)\right]^{\zeta} \\
\tilde{Y}_{N, t}^{j}\left(z_{N}^{j}\right)=A_{N,}^{j}\left[H_{N, t}^{j}\left(z_{N}^{j}\right)\right]^{\zeta}
\end{gathered}
$$

where $\tilde{Y}_{T, t}^{j}\left(z_{T}^{j}\right)$ and $\tilde{Y}_{N, t}^{j}\left(z_{N}^{j}\right)$ denote the output produced by the individual firms, and $A_{T}^{j}$, and $A_{N}^{j}$, are sector-specific exogenous processes that affect the productivity of labour. We interpret the shocks to these processes as 'supply' (or productivity) shocks. The parameter $\zeta$ measures the elasticity of output with respect to labour, and we assume it to be equal across sectors and across countries. Since labour can perfectly move between sectors, traded and nontraded sector firms pay the same hourly real wage rate $w j$.

Prices adjust sluggishly to changes in demand. In particular, we assume that firms have to pay a nonlinear adjustment cost whenever they want to change their prices. For example, a firm $z_{T}^{E}$, operating in Europe's traded goods sector, will choose the price of its own differentiated good by maximising the present discounted value of expected profits:

$$
E_{t} \sum_{i=0}^{\infty} \beta^{i} \frac{\omega_{t+i}^{E}\left(C_{t+i}^{E}\right)^{-\xi_{c}}}{\omega_{t}^{E}\left(C_{t}^{E}\right)^{-\xi_{c}}}\left[\frac{S R_{T, t+i}^{E}\left(z_{T}^{E}\right)}{P_{t+i}^{E}}-H_{T, T+i}^{E}\left(z_{T}^{E}\right) W_{t+i}^{E}\right]
$$

for every $t \in[0, \infty)$. The variable $S R_{T}^{E}\left(z_{T}^{E}\right)$ denotes the sales revenues net of the adjustment cost, and $\widetilde{Y}_{T, t}^{E}\left(z_{T}^{E}\right)$ the demand for the good produced by firm $z_{T}^{E}$ :

$$
\begin{gathered}
S R_{T, t}^{E}\left(z_{T}^{E}\right)=\left[1-\Gamma_{T, t}^{E}\left(z_{T}^{E}\right)\right] P_{E, T, t}^{E}\left(z_{T}^{E}\right) \tilde{Y}_{T, t}^{E}\left(z_{T}^{E}\right) \\
\tilde{Y}_{T, t}^{E}\left(z_{T}^{E}\right)=\frac{1}{\alpha \gamma_{E} \gamma_{P}}\left(\frac{P_{E, T, t}^{E}\left(z_{T}^{E}\right)}{P_{E, T, t}^{E}}\right)^{-\theta}\left[\gamma_{E} \gamma_{P} C_{E T,}^{E}+\left(\gamma_{P}-\gamma_{E} \gamma_{P}\right) C_{E T, t,}^{U}+\left(1-\gamma_{P}\right) C_{E T, t,}^{t}\right]
\end{gathered}
$$


Price-adjustment costs incurred by firm $z_{T}^{E}$ are a function of the change in its own price level:20

$$
\Gamma_{T, t}^{E}\left(z_{T}^{E}\right)=\frac{\phi}{2}\left(\frac{P_{E, T, t}^{E}\left(z_{T}^{E}\right)}{\bar{\pi}^{E} P_{E, T, t-1}^{E}\left(z_{T}^{E}\right)}-1\right)^{2}
$$

where $\bar{\pi}^{E}>1$ denotes the gross steady-state rate of inflation in country E. Firms maximise the expected discounted profits subject to their production function and the demand for their own differentiated good. Non-traded goods sector firms and firms located in country $U$ and $A$ solve a similar maximisation problem.

\subsection{Government}

In all countries, the government represents both the fiscal and monetary authority. Seigniorage revenues are redistributed to the households in the form of net transfers, and in each country $j$ the government runs a balanced budget in every period:

$$
M_{t}^{j}-M_{t-1}^{j}=T_{t}^{j}
$$

We assume that monetary policy follows an interest rate feedback rule, specified in terms of current economic conditions, and that the central bank targets only the inflation rate. Thus, in each country $j$ the nominal interest rate is set according to the following equation:21

$$
\left(1+i_{t}^{j}\right)=\left(1+i_{t-1}^{j}\right)^{\rho_{i}}\left[\left(1+\bar{i}^{j}\right)\left(\frac{\pi_{t}^{j}}{\bar{\pi}^{j}}\right)^{\rho_{\pi}}\right]^{1-\rho_{i}}
$$

where $\rho_{i}$ and $\rho_{\pi}$ are positive parameters, $\bar{i}^{j}$ is the steady-state nominal interest rate, and $\pi j$ is country $j$ 's gross inflation rate at date $t$. We abstract from the specification of an optimal rule, and set the inflation target equal to its steady-state gross rate $\bar{\pi}^{j}$. When Asia pegs its currency to the dollar, its monetary policy rule is simply replaced by the requirement to maintain the peg.

\subsection{The uncovered interest rate parity condition}

The uncovered interest parity (UIP) condition holds in the model. As in Benigno (2009), it is modified to take into account the cost of holding bonds. The UIP can be easily derived from the first-order approximated solution; for example, a simple manipulation of the linearised Euler equations for consumption in country $j$ leads to the following relationship between US and 
Asian interest rates:22

$$
E_{t} \hat{\varepsilon}_{T+1}^{U}-\hat{\varepsilon}_{T}^{U}+\eta\left(\frac{B_{U, t}^{j}}{P_{t}^{j}} \frac{\varepsilon_{t}^{j}}{\varepsilon_{t}^{U}}-\frac{B_{A, t}^{j}}{P_{t}^{j}} \varepsilon_{t}^{j}\right)=\beta\left(i_{t}^{U}-i_{t}^{A}\right)
$$

A similar UIP condition holds between European and Asian interest rates, and between European and US rates. When Asia pegs its currency to the dollar, its interest rate will have to adjust to the US interest rate.

\section{Calibration AND SOlution}

\subsection{Calibration of the model}

We conduct our analysis using a calibrated version of the model, choosing the structural parameters from the literature, with the aim of approximating the salient features of the US, European and Asian economies. Our main reference for the calibrated parameter values is Obstfeld and Rogoff's (2005) threecountry model, but we also conduct a sensitivity analysis in Section 6. The calibrated parameter values are generally symmetric across countries, and reported in Table 1 .

\begin{tabular}{ll}
\hline & Table 1: Parameter Values \\
\hline Preferences & $\beta=0.99, \xi_{C}=5, \xi_{H}=2.33, \varphi=12.74$ \\
Relative sizes & $\gamma_{E}=1 / 2, \gamma_{P}=2 / 3$ \\
Consumption indices & $\alpha=0.36, \mu=1, h^{E}=4.67, h^{U}=4.67, h^{A}=4.67, \rho=2, \psi=2, \varphi=7.88$ \\
Production & $\xi=0.8$ \\
Adjustment costs & $\phi=77, \eta=0.0025$ \\
Interest rate rule & $\rho_{\imath}=0.81, \rho_{\pi}=1.52$ \\
& \\
Exogenous processes: & \\
AR coefficients & $\rho_{T}=0.81, \rho_{N}=0.81, \rho_{\omega}=0.33$ \\
Std deviations: Europe & $\sigma_{T}^{E}=0.015, \sigma_{N}^{E}=0.015, \sigma_{\omega}^{E}=0.03$ \\
Std deviations: US & $\sigma_{T}^{U}=0.01, \sigma_{N}^{U}=0.01, \sigma_{\omega}^{U}=0.02$ \\
\hline
\end{tabular}

Because of the uncertainty about the properties of the shocks and the values for the parameters that appropriately characterise Europe, the United States and Asia, we prefer to make only minimal restrictions. In Section 6 we check whether our main results are robust to changes in parameter values. In this way, although our research is largely motivated by China's present dilemma over fixed, managed or flexible exchange rates, we are also able to assess 
whether a third country's choice of exchange rate regime can affect the transmission of shocks between any two other countries in general terms.

The discount factor $\beta$ is set so as to yield an annual real interest rate of four percent in the steady state, and the risk aversion parameter $\xi_{C}$ is taken from Chari et al (2002). The parameter $\varphi$ is calibrated so that in the steady state the fraction of time that households in all countries or regions spend working is 0.31 . Then, given this choice of average hours worked in the steady state, the parameter $\xi_{H}$ is calibrated so that in the steady state the Frisch elasticity of labour supply is equal to 1, the value suggested by Gali et al (2007). The interest rate feedback rule makes the money demand equation redundant (money demand adjusts automatically to money supply), therefore the parameters $\chi$ and $\xi_{M}$ need not be calibrated.

The parameters $\gamma_{E}$ and $\gamma_{P}$ govern the 'size' of the three regions in the model, with $\gamma_{E}$ denoting the size of Europe and $\gamma_{P}$ denoting the combined size of Europe and the US. In particular, both $\gamma_{E}$ and $\gamma_{P}$ simultaneously accomplish several roles within the model, since they give the measure of households, firms and product varieties in each region, in addition to being the weights of the consumption indices for traded goods. Therefore, $\gamma_{E}$ and $\gamma_{P}$ could be calibrated using population data, GDP data, or trade data, leading to very different calibrations. 23 Because of this ambiguity we decide to take a 'neutral' or intermediate stance, we assume that all regions have the same size, and we assume all other major parameters are symmetric across all countries. We conduct sensitivity analysis with respect to $\gamma_{E}$ in Section 6 . This approach has an additional benefit - keeping the major parameters the same across all countries allows for a clearer understanding of the transmission mechanism because, following the US shock, the only difference between Europe's and Asia's reaction is caused by their different choices of exchange rate regime.

The critical parameters in the model are $\mu$, the elasticity of substitution in consumption between traded and non-traded goods, $\psi$, the elasticity of substitution between European and US traded goods, and $\rho$, the elasticity of substitution between Asian goods and the bundle formed by European and US traded goods. The values for these elasticities are all taken from Obstfeld and Rogoff (2005).24 The home bias parameters $h^{E}, h^{U}$ and $h^{A}$ are chosen so as to get close to the values suggested by Obstfeld and Rogoff, 25 given our choice of country weights $\gamma_{E}$ and $\gamma_{P}$. The share of traded goods $\alpha$ is based upon the estimates of Spange and Zabczyk (2006), and the parameter $\theta$ is taken from Rotemberg and Woodford (1998). However, since the elasticities of substitution, the degree of home bias, and the share of traded goods in total consumption are crucial for the transmission of shocks across countries, we conduct extensive sensitivity analysis with respect to these parameters in Section 6 . 
The elasticity of output with respect to hours $\xi$ is calibrated so that, given the mark-up, 26 in the steady state the share of wages in the value of output is equal to 0.7 , a value that is taken from Rotemberg and Woodford (1999). Our choice of the price-adjustment cost parameter $\phi$ is based upon the estimates of Ireland (2001), while $\eta$, the parameter that governs the size of the bond-adjustment costs, is taken from Ghironi and Melitz (2005).

The coefficients of the interest rate feedback rule, $\rho_{i}^{j}$ and $\rho_{\pi}^{j}$, are set in accordance with IMF calculations. We too assume that these coefficients are the same across countries or regions, and in Section 6 we conduct sensitivity checks.

We decide to adopt an 'agnostic' approach, and assume that the exogenous processes that affect demand and productivity are the same across countries. They are all assumed to follow stationary AR(1) processes with zero mean, and the shocks to these processes are uncorrelated. Our research question is restricted to be the analysis of how the transmission of US shocks to Europe is affected by the choice of the exchange rate regime in Asia. Therefore, for the sake of clarity, we abstract from all shocks originating in Asia.

The autoregressive parameters are taken from Benigno and Thoenissen (2003), and Neiss and Nelson (2003). We normalise the standard deviations of the two productivity shocks as being half the standard deviation of the demand shock, so as to avoid giving more importance to either demand or supply shocks. Finally, we choose the standard deviations of the two demand shocks so as to approximate the standard deviation of output in Europe and the United States.

\subsection{Solution of the model}

Since the model cannot be solved in closed-form, we obtain our results by means of a numerical approximated solution. In particular, we find the steady state of the nonlinear model using Mathematica, 28 and then we use DYNARE to compute the first-order approximate solution of the model, the impulse response functions, the second-order moments and the variance decompositions. ${ }^{29}$

\section{THE TRANSMISSION OF US SHOCKS TO EUROPE}

In this section we explain how sector-specific productivity shocks and demand shocks originating in the United States are transmitted to Europe's output and inflation, and how the transmission is affected by Asia's choice of exchange rate regime. For each shock we first describe the international transmission mechanism when all three currencies freely float against each other, a situation that we call the floating scenario. Then we examine how the international transmission mechanism changes when we allow Asia to peg its currency to the dollar, a situation we call the hybrid scenario, because different exchange rate regimes coexist. 30 
The impulse responses for the main macroeconomic variables described in the previous sections are presented in the appendices. We also present the responses of the three bilateral real exchange rates and the three bilateral terms of trade, which are defined as follows:

$$
R E R_{j, t}^{j^{\prime}} \equiv \frac{P_{t}^{j}}{P_{t}^{j^{\prime}}} \frac{\varepsilon_{t}^{j^{\prime}}}{\varepsilon_{t}^{j}} \quad, \quad T o T_{j, t}^{j^{\prime}} \equiv \frac{P_{j, T, t}^{j}}{P_{j^{\prime}, T, t}^{j^{\prime}}} \frac{\varepsilon_{t}^{j^{\prime}}}{\varepsilon_{t}^{j}}
$$

For example, a rise in $R E R_{E, t}^{U}$ is an increase in the price of Europe's consumption basket relative to the US consumption basket, therefore we say that Europe's real exchange rate appreciates and the US real exchange rate depreciates. A rise in $T o T_{E, t}^{U}$ is an increase in the price of Europe's traded goods relative to US traded goods, therefore we say that Europe's terms of trade improves and the US terms of trade deteriorates.

The following example explains why shocks in the United States affect aggregate demand for Europe's output through several channels. First, any shock that raises US consumption, increases US demand for worldwide, and thus Europe's output (the aggregate world demand effect). The aggregate demand for Europe's output is further affected by the consequent reaction of consumption in Europe and in Asia. Second, aggregate demand for Europe's output depends not only on aggregate world consumption, but also on the allocation of consumption across countries, because households are biased towards consuming domestic products. Hence, a unit increase in consumption in Asia has a different effect on demand for Europe's output than a unit increase in consumption in Europe. Third, the allocation of consumption over time (consumption smoothing) also affects the demand for Europe's output by changing its pattern over time, and thus by changing the volatility of demand. The strength of many of these effects depends on the choice of the exchange rate regime.

Thus, in a general equilibrium model, all the variables are interrelated and the channels that allow the shocks to have an effect on the world economy can be numerous. However, as far as the transmission across countries is concerned, our analysis is greatly facilitated by the recognition that in our model there are only two sources of international linkages, namely trade and the asset market.

The international transmission through trade can be summarised as follows. International trade flows are affected by all bilateral terms of trade, which measure the competitiveness of a country's traded output vis-à-vis another country's. In addition to having other effects on the domestic economy, a shock originating in one country will change its two bilateral terms of trade, either through a change in the price of that country's traded output, or through a change in the value of the currency (nominal exchange rate). As a result, the other countries' competitiveness will also be affected by the shock. 
Adjustment towards equilibrium in the goods market will require a change in all countries' traded output.

The international transmission through the asset market can be summarised as follows. A shock originating in one country will affect its desired intertemporal allocation of consumption, and therefore its demand or supply of the internationally traded bonds. For example, a country that wants to increase future consumption will start lending and thereby have a higher demand for bonds. Since bonds are in zero net supply worldwide, the adjustment towards equilibrium in the asset market will require changes in the cost of borrowing and bond holdings in the other two countries which, in turn, will affect their intertemporal allocation of consumption. We recover this mechanism by examining the changes in the real interest rates, which we define as follows: 31

$$
r_{t}^{j} \equiv E_{t}\left[\frac{1+i_{t}^{j}}{1+\eta\left(\frac{B_{j, t}^{j}}{P_{t}^{j}}\right)} \frac{P_{t}^{j}}{P_{t+1}^{j}}\right]-1
$$

The above definition of the real interest rate is useful because consumption growth in country $j$ is positive (negative) whenever $r_{t}^{j}$ is positive (negative). ${ }^{32}$ Thus, changes in $r_{t}^{j}$ capture the international transmission of the shock through the asset market.

Throughout the analysis, we describe the transmission of each shock originating in the United States by means of a simple step-by-step approach. First, we describe its direct effects on the US economy. Then, we examine its consequences for terms of trade and for the asset market, and from those consequences we explain why we get the observed responses of output and inflation in Europe. The main interest of this analysis lies in the interpretation of the results presented in Section 6: without an understanding of the transmission mechanism, we would not be able to explain and determine the limits of our findings.

\subsection{Positive productivity shock in the US traded goods sector}

\section{Floating scenario 33}

To begin with, all the firms operating in the traded sector enjoy higher productivity of labour, and therefore lower real marginal costs. Under monopolistic competition, prices increase when current and expected future marginal costs increase. Therefore the positive productivity shock, which reduces marginal costs, causes a fall in the US traded goods price index, which is also accompanied by an increase in traded output. Because of the increase in trad- 
ed output, US GDP increases. Lower prices and higher income stimulate households' demand, increasing consumption in the United States.

Second, US firms in the traded sector react to the increase in the productivity of labour by shrinking their workforce. The resulting fall in labour demand causes a fall in the common wage rate, 34 therefore marginal costs fall also for the firms operating in the non-traded sector. As a result, prices fall also in the non-traded sector and US CPI inflation falls. The US monetary authority reacts by cutting the nominal interest rate, thus US consumption demand receives a further boost.

Moreover, the shock is transmitted to the other countries through trade and the asset market. Higher US consumption will push up demand for all goods, and thus increase international trade. Because of the lower US nominal interest rate, however, there is an expected and actual appreciation of the dollar in all periods after the shock, as predicted by the UIP condition. That said, the dollar's appreciation does not erode the US competitive gain induced by falling US traded goods prices, so both bilateral terms of trade for US goods deteriorate. As a result, world demand now switches towards the cheaper US traded goods.

In order to spread the benefit (in terms of higher consumption) of the shock into the future, US households lend money abroad and the US current account becomes positive. Real interest rates fall in the other two countries. 35 Low real interest rates induce foreign households to fund their current consumption by borrowing from the United States. As a result, consumption in both Europe and Asia increases.

The response of European output depends on the relative strength of several factors. ${ }^{36}$ On the one hand, the worldwide increase in consumption and the depreciation of the euro stimulates production. On the other hand, world demand switches towards the cheaper US traded goods. We can see from Figure 1 (see Appendix) that the latter effect prevails, since output in Europe falls. It is also important to recall that, under the floating scenario, Europe and Asia are perfectly symmetric. Therefore the positive productivity shock in the US traded sector affects both of them in the same way.

Finally, under monopolistic competition and sticky prices, domestically-set prices depend on current and future expected marginal costs, which in our set-up depend on both wages and the level of output. ${ }^{37}$ After a positive productivity shock in the US traded sector, marginal costs decrease in both Europe and Asia. This, plus the fall in the US traded prices, explains the decrease in domestic (and CPI) inflation rates in both countries, which in turn induces their central banks to cut nominal interest rates. However, since Europe and Asia do not benefit from the direct effect of the productivity shock on domestic prices, their falls in inflation rates and the subsequent expansionary responses from the monetary authorities are milder than in the United States. 


\section{Hybrid scenario}

Under the hybrid scenario, the direct effects on the US economy of the positive productivity shock in the US traded goods sector are the same as before, but the international transmission changes. Now, in order to preserve the fixed exchange rate against the dollar, the nominal interest rate in Asia must fall to the same level as the US nominal interest rate. Although in principle this could have implications for the transmission of the shock through the asset market, we can see from the impulse responses that bond holdings 38 in the three countries are affected in a very similar way under the two scenarios; moreover, the responses of consumption in Europe and the United States are also very similar. Therefore, we can infer that in the case of this shock, Asia's choice of exchange rate regime does not have a major influence on the intertemporal allocation of consumption in the other two countries. The asset market is not affected significantly.

The source of the differences in the responses of European output and inflation under the hybrid scenario is international trade flows. Because the Asian currency cannot depreciate vis-à-vis the dollar, it must appreciate visà-vis the European currency. These nominal exchange rate effects influence the transmission of the shock through international trade. At first, we would expect an increase in the competitiveness of European traded goods in comparison with Asian traded goods, and an increase in Europe's output at the expense of Asian output. However, competitiveness and international trade flows are not only affected by nominal exchange rates, but also by relative prices. As we can see from the impulse responses, Asian traded goods inflation is more negative under the hybrid than under the floating scenario.

This marked fall of Asian prices helps to stabilise the US/Asia terms of trade, and allows Asian firms to stay competitive vis-à-vis the United States. On the other hand, the marked fall of Asian traded goods prices also works in the direction of increasing the price of European goods relative to Asian goods. This erodes the competitive gain induced by the depreciation of the euro towards the Asian currency. Indeed, Figure 1 shows that initially the Europe/Asia terms of trade increases rather than decreases. As a result, there is an expenditure-switching effect away from European goods to Asian goods, which causes European output, initially, to fall more under the hybrid than under the floating scenario. Since output falls more, future expected marginal costs are lower, at least initially, thus explaining why domestic (and CPI) inflation in Europe falls more under the hybrid than under the floating scenario.

\subsection{Positive productivity shock in the US non-traded goods sector}

For the sake of brevity, we analyse the transmission of the non-traded productivity shock mainly by explaining how it differs from the transmission of the traded productivity shock. 


\section{Floating scenario39}

The direct effect on the United States of the positive productivity shock in the US non-traded sector is very similar to that of the traded productivity shock. Production increases and real marginal costs fall, triggering a reduction in the price of non-traded goods. Since the US economy now produces more output at cheaper prices, domestic consumption increases. US demand gradually switches to the relatively cheaper non-traded goods, thus causing a fall in expected future traded output and real marginal costs in the traded goods sector. As a result, US traded goods prices fall too. The fall in domestic (and as a result, CPI) inflation prompts the US central bank to lower the nominal interest rate. As in the case of the traded sector productivity shock, the non-traded productivity shock is transmitted abroad through the asset market and trade.

The fall in US prices induces the US central bank to reduce the nominal interest rate. As in the case of the traded sector productivity shock, the dollar appreciates, but the appreciation of the dollar is a lot stronger under the non-traded productivity shock than under the traded productivity shock. 40 Moreover, the nominal appreciation does not erode the US' competitive gain, and both bilateral terms of trade for US goods deteriorate. ${ }^{41}$ Notwithstanding the increase in domestic consumption and the depreciation of the euro, European output falls, since demand switches towards the cheaper US traded goods. ${ }^{42}$ Because of the decrease in wages and output, current and future expected marginal costs fall, therefore domestic (and CPI) inflation in Europe falls initially. The fall in inflation is short-lived because the depreciation of the euro increases the cost of imports. Moreover, as Europe's output levels start to grow, so do marginal costs and therefore prices.

\section{Hybrid scenario}

In the previous section we saw that Asia's choice of exchange rate regime did not affect significantly the transmission of the traded productivity shock through the asset market. This is not the case here. Following the non-traded productivity shock, Asia's borrowing is lower under the hybrid than under the floating scenario, and real interest rates in both Europe and Asia fall more. As a result, Europe's consumption initially increases more under the hybrid than under the floating scenario.

As in the case of the traded productivity shock, the main driver of the differences in the responses of European output and inflation under the hybrid scenario is the marked fall in Asian prices. From Figure 2 (see Appendix) we can see that in the hybrid scenario the fall in Asian prices and inflation rates (both traded and non-traded) is quite dramatic, except for a small and very short-lived initial increase. As before, this allows Asian traded sector firms to stay competitive vis-à-vis US firms. 
The marked fall in Asian prices induces an expenditure-switching effect from European and US goods to Asian goods. As a result, Europe's output initially must fall below the level that occurs under the floating scenario. Moreover, European wages also fall below the level that occurs under the floating scenario. As a result, expected future marginal costs are comparatively lower and prices in Europe fall more thus explaining why, initially, domestic (and CPI) inflation rates in Europe fall below the floating scenario. Nevertheless, after several periods Europe's output benefits from the appreciation of the Asian currency, and thus European output and inflation gradually rise above the floating scenario.

By and large, the mechanism of the adjustment of inflation and output in Europe, following a non-traded sector shock in the United States, is similar to that caused by the traded sector shock. However, the quantitative difference between the hybrid and floating scenario is much larger when the shock originates in the non-traded sector.

\subsection{Negative demand shock in the United States}

In this section we analyse the transmission of a negative US demand shock. Although less detailed than Section 4.1, the explanation offered here follows the same step-by-step approach.

\section{Floating scenario 43}

A negative demand shock induces a decline of consumption demand in the United States and, since output is demand-determined in the model, current and expected future output fall. Expected future marginal costs, which depend on both wages and output, are lower, so prices fall too. The US monetary authority reacts by cutting the nominal interest rate and the dollar gradually appreciates, as predicted by the UIP condition.

The demand shock is transmitted to the other countries through the asset market and trade. Since the negative demand shock reduces the attractiveness of consumption, US households lend resources abroad. Real interest rates fall in the other two countries and borrowing becomes more attractive to European and Asian households, thus consumption rises in the other countries. Additionally, since both bilateral terms of trade for US goods deteriorate, world demand switches towards the US traded goods.

As with the other shocks, the response of European output depends on the sign, and the relative strength, of the changes in all the variables that affect the demand for European output: relative price and domestic and foreign consumption demands. On the one hand, both the depreciation of the euro and the increase in domestic consumption stimulate the demand for European goods. On the other hand, the falls in both US prices and US consumption reduce the demand for European goods. It is possible to infer from Figure 3 (see Appendix) that the latter factors dominate, since Europe's out- 
put falls, although in the long-run it increases slightly. In turn, falling output and lower wages imply lower current and expected future marginal costs, therefore European prices fall and inflation is negative. However, in subsequent periods inflation becomes mildly positive in all three countries.

\section{Hybrid scenario}

Asia's choice of exchange rate regime does not alter significantly the transmission of the demand shock through the asset market. This result can be inferred by noting that the responses of bond holdings are little different under the two scenarios. As before, the main driver of the differences in the responses of European output and inflation under the hybrid scenario is the marked fall in Asian prices.

As with the two productivity shocks, under the hybrid scenario the Europe/Asia terms of trade increases initially, so Europe's competitive position towards Asia deteriorates, and Europe's output falls initially below the level that occurs under the floating scenario. Moreover, because output and wages fall more, current and expected future marginal costs are comparatively lower therefore, initially, domestic (and CPI) inflation rates in Europe fall below the level that occurs under the floating scenario. However, the differences in the responses of the European variables between the two scenarios are minimal under the demand shock.

In conclusion, Section 4 has shown that the amplification of the responses of European output and inflation in the hybrid scenario is caused by the behaviour of Asian firms. The impulse responses show that, whenever the Asian currency is pegged to the dollar, Asian firms respond to any shock that causes US prices to fall by cutting their prices dramatically. ${ }^{44}$ In practice, these price cuts allow Asian firms to remain competitive in the face of falling US prices and no nominal exchange rate adjustment. 45, 46, 47 However, this behaviour damages European firms. We have found that the fall in Asian prices more than erodes the competitive gain induced by the depreciation of the euro against the Asian currency. The Europe/Asia terms of trade increases, and Europe's output and inflation fall below the levels that occur under the floating scenario.

Additionally, Section 4 has illustrated that Asia's adoption of a fixed exchange rate vis-à-vis the dollar has two important effects. The first one is that, after a positive productivity or a negative demand shock in the United States, the Asian currency must appreciate vis-à-vis the euro, and the second one is that the nominal interest rate in Asia must fall at the same level as the US nominal interest rate. However, our three-country model shows that these effects are quantitatively less important than the fall in Asian prices. 48

5. Assessing THE EXPOSURE OF EUROPE'S OUTPUT AND INFLATION TO US SHOCKS Table 2 reports the standard deviations of the main macroeconomic variables in the model, under the fixed and floating scenarios. Considering the relatively stylised nature of the model, we think that the standard deviations produced by the model are generally consistent with the data, except for the real 
exchange rate. However, the ability of sticky price models to reproduce the high volatility of the real exchange rates found in the data is currently under investigation in the literature. 49 Notably, Asia's choice of exchange rate regime does not affect significantly the European business cycle, since the volatility of the main macroeconomic variables remains the same under both scenarios. 50

Table 2: Volatility of European and Model-Generated Time Series: Percent Standard Deviations

\begin{tabular}{|c|c|c|c|}
\hline & Data & Mloating & Hybrid \\
\hline Inflationa & 0.26 & 0.31 & 0.31 \\
\hline Outputa & 0.84 & 0.65 & 0.65 \\
\hline Consumptiona & 0.79 & 0.62 & 0.62 \\
\hline Current account/GDPb & 0.52 & 0.23 & 0.24 \\
\hline US-Europe real exchange ratea & 8.01 & 1.07 & 1.07 \\
\hline Nominal interest ratec & 0.15 & 0.18 & 0.18 \\
\hline \multicolumn{4}{|c|}{$\begin{array}{l}\text { NOTE: Wages are given by Compensation of Employees divided by the aggregate price level. } \\
\text { European inflation is defined as the quarter-to-quarter growth rate in the euro area CPI } \\
\text { (OECD aggregation). The US-Europe real exchange rate series has been constructed using the } \\
\text { US and euro area CPI indexes, and the bilateral nominal exchange rate. The nominal interest } \\
\text { rate is the 3-month interbank rate. The price levels and the other variables have been sea- } \\
\text { sonally adjusted, logged and HP-filtered with } \lambda=1,600 \text {. Current account and interest rates } \\
\text { have not been logged. Sources: Authors' calculations based on OECD, Eurostat and IMF data. } \\
\text { All data series are of quarterly frequency and refer to the euro area. } \\
\text { a Sample: } 1980: 1 \text { to } 2005: 3 \text {. } \\
\text { b Sample: } 1995: 1 \text { to } 2005: 3 \text {. } \\
\text { c Sample: } 1994: 1 \text { to } 2005: 3 \text {. }\end{array}$} \\
\hline
\end{tabular}

In order to assess the overall impact of Asia's choice of exchange rate regime, we look at the variance decompositions of output and inflation, which are reported in Table 3. The results show that if Asia keeps the exchange rate pegged to the dollar, Europe's exposure to US shocks increases, since the percentages of the variance of Europe's output and inflation that are due to US shocks are higher under the hybrid scenario than under the floating scenario. However, in our calibration, US shocks account for only a small percentage of the variances of Europe's output and inflation, which explains why Europe's overall volatility is little affected.

Table 3 can easily be understood by means of the main results established in the analysis of the transmission mechanism. Consider, for example, a shock that causes US prices to fall, such as any one of the three shocks analysed in Section 4. In all three cases output and inflation in Europe fall more, at least at impact, under the hybrid scenario than under the floating scenario. Therefore, if Asia keeps its currency fixed against the 
dollar the responses of Europe's output and inflation after a US shock are amplified.

Table 3: Variance decomposition: percentage of the total variance of European variables explained by US shocks

\begin{tabular}{lcccc}
\hline & Traded & Non-traded & Demand & Total \\
& \multicolumn{4}{c}{ Floating scenario } \\
Output & 0.18 & 0.35 & 0.15 & $\mathbf{0 . 6 8}$ \\
Inflation & 0.65 & 0.66 & 0.05 & $\mathbf{1 . 3 6}$ \\
& \multicolumn{4}{c}{ Hybrid scenario } \\
Output & 0.19 & 0.71 & 0.16 & $\mathbf{1 . 0 6}$ \\
Inflation & 0.72 & 1.54 & 0.06 & $\mathbf{2 . 3 2}$ \\
NOTE: Inflation is defined as the quarter-to-quarter growth rate in the aggregate price level. \\
$\begin{array}{l}\text { The statistics are computed from logged and HP-filtered series, with } \lambda=1,600 \text {. The variance } \\
\text { decompositions are computed by DYNARE using first-order approximations of the model. }\end{array}$ \\
\hline
\end{tabular}

Table 3 further shows that the main contribution to the exposure of Europe's output and inflation to US shocks comes from the non-traded productivity shock. This is because the non-traded sector in the United States is twice as large as the traded sector, and consequently the reaction of the US monetary policy to non-traded shocks is much larger.

Moreover, the non-traded productivity shock is a major contributor to the higher exposure of Europe's output and inflation in the hybrid scenario. This is because the appreciation of the dollar vis-à-vis the Asian currency in the floating scenario is more pronounced with this shock. In practice, the strong dollar appreciation moderates the loss of competitiveness of Asian goods and restores the equilibrium in the goods market. But in the hybrid scenario, a severe cut in Asian prices replaces the strong dollar appreciation as a means to achieve the adjustment in the terms of trade dictated by supply and demand conditions. This preserves the competitiveness of Asian firms, but creates additional volatility in Europe's output and inflation in case of this shock.

One should bear in mind that, for our calibration, the responses of European output and inflation to shocks originating in Europe are the same in the hybrid as in the floating scenario. This can be inferred as a corollary from the analysis of Section 4. Since Europe and the United States are symmetric, under the floating scenario the responses of European variables to US shocks are identical to the responses of US variables to shocks originating in Europe. 51 In the floating scenario, a shock originating in the United States does not affect the Europe/Asia nominal exchange rate. Analogously, after a 
shock originating in Europe, the US/Asia nominal exchange rate does not change. As a result, Asia's choice of exchange rate regime does not affect the responses of Europe's output and inflation to domestic shocks.

\section{SEnsitivity analysis}

In order to check whether the results illustrated in Section 5 are robust to changes in the values of the parameters, we consider several departures from our baseline calibration. In this way, we are also able to assess whether our findings hold in general terms, for any group of three large countries in the world economy. 52

Specifically, to conduct our sensitivity checks we analyse both the impulse responses and the variance decompositions obtained under alternative parameterisations of the model, which differ from the baseline calibration in respect of only one parameter at a time. To save space, we report only the variance decompositions in Table 4.53 Our results show that, under all alternative parameterisations, 54 if Asia pegs its currency to the dollar, Europe's exposure to US shocks is higher - the percentages of the variance of European output and inflation that are caused by US shocks are always higher in the hybrid than in the floating scenario.

This is not the only robust result. One additional result that emerged from Section 4 was that the cause of the increase in Europe's exposure to US shocks is the behaviour of Asian prices in the hybrid scenario. Indeed, the impulse responses for our baseline calibration show that, whenever the Asian currency is pegged to the dollar, Asian firms respond to any shock that causes US prices to fall by markedly cutting their prices. As a result, at least at impact, Europe experiences a higher loss of output demand if Asia pegs its exchange rate to the dollar. By analysing the impulse responses, we have found that the same happens in the alternative parameterisations considered in Table 4.55 Moreover, these impulse responses under alternative parameterisations also confirm that the difference between the responses of Asian prices in the two scenarios is much larger in the case of a US non-traded productivity shock than with the other two considered shocks.

In summary, the following three results are robust to changes in parameter values: 1) if Asia keeps its exchange rate pegged to the dollar, both output and inflation in Europe respond more to US shocks; 2) the amplification of the responses of European output and inflation is attributable to the behaviour of Asian prices in the hybrid scenario; 3) this amplification is always more marked in the case of US non-traded productivity shocks. 56

Another result, which can be deduced from Table 4, is that changes in parameter values affect both the overall contribution of US shocks to the variances of European output and inflation, and the relative contribution of each US shock in comparison with the others. Hereafter, we discuss some of the more interesting examples. 
Table 4: Sensitivity analysis

\begin{tabular}{|c|c|c|c|c|c|c|c|c|}
\hline & Traded & $\begin{array}{l}\text { Non } \\
\text { traded } \\
\text { Floating }\end{array}$ & $\begin{array}{l}\text { Demand } \\
\text { scenario }\end{array}$ & Total & Traded & $\begin{array}{c}\text { Non } \\
\text { traded } \\
\text { Hybrid }\end{array}$ & scenario & Total \\
\hline & & & & & & & & \\
\hline Output & 0.24 & 0.31 & 0.14 & 0.69 & 0.26 & 0.68 & 0.15 & 1.09 \\
\hline \multirow[t]{2}{*}{ Inflation } & 0.55 & 0.39 & 0.02 & 0.96 & 0.61 & 1.12 & 0.02 & 1.75 \\
\hline & \multicolumn{8}{|c|}{$\xi_{H}=9.68$} \\
\hline Output & 0.04 & 0.23 & 0.14 & 0.41 & 0.05 & 0.41 & 0.16 & 0.62 \\
\hline \multirow[t]{2}{*}{ Inflation } & 0.95 & 1.79 & 0.25 & 2.99 & 1.03 & 2.92 & 0.29 & 4.24 \\
\hline & \multicolumn{8}{|c|}{$\gamma_{E}=0.20$} \\
\hline Output & 0.51 & 1.17 & 0.57 & 2.25 & 0.55 & 1.88 & 0.59 & 3.02 \\
\hline \multirow[t]{2}{*}{ Inflation } & 3.26 & 3.41 & 0.27 & 6.94 & 3.47 & 6.20 & 0.30 & 9.97 \\
\hline & \multicolumn{8}{|c|}{$\gamma_{E}=0.80$} \\
\hline Output & 0.02 & 0.05 & 0.02 & 0.09 & 0.02 & 0.19 & 0.03 & 0.24 \\
\hline \multirow[t]{2}{*}{ Inflation } & 0.07 & 0.07 & 0.01 & 0.15 & 0.07 & 0.34 & 0.01 & 0.42 \\
\hline & \multicolumn{8}{|c|}{$\gamma_{P}=0.20$} \\
\hline Output & 0.01 & 0.05 & 0.04 & 0.10 & 0.01 & 0.92 & 0.06 & 0.99 \\
\hline \multirow{2}{*}{ Inflation } & 0.18 & 0.21 & 0.02 & 0.41 & 0.24 & 4.29 & 0.04 & 4.57 \\
\hline & \multicolumn{8}{|c|}{$\gamma_{P}=0.80$} \\
\hline Output & 0.25 & 0.46 & 0.18 & 0.89 & 0.26 & 0.67 & 0.19 & 1.12 \\
\hline \multirow[t]{2}{*}{ Inflation } & 0.76 & 0.76 & 0.06 & 1.58 & 0.80 & 1.23 & 0.06 & 2.09 \\
\hline & \multicolumn{8}{|c|}{$\alpha=0.20$} \\
\hline Output & 0.04 & 0.21 & 0.05 & 0.30 & 0.04 & 0.44 & 0.05 & 0.53 \\
\hline \multirow[t]{2}{*}{ Inflation } & 0.10 & 0.26 & 0.01 & 0.37 & 0.10 & 0.61 & 0.01 & 0.72 \\
\hline & \multicolumn{8}{|c|}{$\alpha=0.50$} \\
\hline Output & 0.42 & 0.34 & 0.28 & 1.04 & 0.49 & 0.68 & 0.29 & 1.46 \\
\hline \multirow[t]{2}{*}{ Inflation } & 1.96 & 0.86 & 0.11 & 2.93 & 2.27 & 1.97 & 0.13 & 4.37 \\
\hline & \multicolumn{8}{|c|}{$\mu=0.50$} \\
\hline Output & 0.10 & 0.19 & 0.08 & 0.37 & 0.10 & 0.47 & 0.09 & 0.66 \\
\hline \multirow[t]{2}{*}{ Inflation } & 0.24 & 0.38 & 0.02 & 0.64 & 0.24 & 0.96 & 0.03 & 1.23 \\
\hline & \multicolumn{8}{|c|}{$\mu=1.50$} \\
\hline Output & 0.28 & 0.48 & 0.23 & 0.99 & 0.33 & 0.86 & 0.24 & 1.43 \\
\hline \multirow[t]{2}{*}{ Inflation } & 1.37 & 0.88 & 0.09 & 2.34 & 1.61 & 1.89 & 0.10 & 3.60 \\
\hline & \multicolumn{8}{|c|}{$h^{E}=h^{U}=h^{A}=7$} \\
\hline Output & 0.14 & 0.24 & 0.09 & 0.47 & 0.17 & 0.51 & 0.10 & 0.78 \\
\hline \multirow[t]{2}{*}{ Inflation } & 0.40 & 0.39 & 0.03 & 0.82 & 0.47 & 0.92 & 0.04 & 1.43 \\
\hline & \multicolumn{8}{|c|}{$h^{E}=h^{U}=h^{A}=1$} \\
\hline Output & 0.10 & 0.74 & 0.65 & 1.49 & 0.09 & 1.31 & 0.66 & 2.06 \\
\hline Inflation & 2.16 & 2.48 & 0.19 & 4.83 & 1.91 & 5.61 & 0.21 & 7.73 \\
\hline
\end{tabular}

Continued... 


\section{Table 4}

...Continued

\begin{tabular}{|c|c|c|c|c|c|c|c|c|}
\hline & & & & & 1.5 & & & \\
\hline Output & 0.03 & 0.19 & 0.15 & 0.37 & 0.04 & 0.35 & 0.16 & 0.55 \\
\hline Inflation & 0.56 & 0.59 & 0.05 & 1.20 & 0.63 & 1.02 & 0.05 & 1.70 \\
\hline & & & & & 3.0 & & & \\
\hline Output & 0.71 & 0.84 & 0.17 & 1.72 & 0.72 & 1.47 & 0.18 & 2.37 \\
\hline Inflation & 0.90 & 0.88 & 0.06 & 1.84 & 0.92 & 2.22 & 0.07 & 3.21 \\
\hline & & & & & 0.10 & & & \\
\hline Output & 0.29 & 0.38 & 0.17 & 0.84 & 0.30 & 0.51 & 0.18 & 0.99 \\
\hline Inflation & 0.78 & 0.47 & 0.19 & 1.44 & 0.81 & 0.81 & 0.21 & 1.83 \\
\hline & & & & & 400 & & & \\
\hline Output & 0.07 & 0.21 & 0.16 & 0.44 & 0.09 & 0.57 & 0.16 & 0.82 \\
\hline Inflation & 0.52 & 0.84 & 0.02 & 1.38 & 0.62 & 2.32 & 0.02 & 2.96 \\
\hline & & & & & 1.0 & & & \\
\hline Output & 0.21 & 0.36 & 0.15 & 0.72 & 0.23 & 0.73 & 0.16 & 1.12 \\
\hline Inflation & 0.56 & 0.58 & 0.03 & 1.17 & 0.63 & 1.42 & 0.04 & 2.09 \\
\hline & & & & & 0.80 & & & \\
\hline Output & 0.14 & 0.65 & 0.14 & 0.93 & 0.21 & 1.95 & 0.19 & 2.35 \\
\hline Inflation & 0.90 & 2.21 & 0.08 & 3.19 & 1.23 & 6.70 & 0.13 & 8.06 \\
\hline & & & & & 1.01 & & & \\
\hline Output & 0.26 & 0.27 & 0.17 & 0.70 & 0.26 & 0.34 & 0.17 & 0.77 \\
\hline Inflation & 0.74 & 0.30 & 0.03 & 1.07 & 0.73 & 0.35 & 0.03 & 1.11 \\
\hline & & & & & .125 & & & \\
\hline Output & 0.16 & 0.28 & 0.19 & 0.63 & 0.15 & 0.51 & 0.24 & 0.90 \\
\hline Inflation & 0.29 & 0.24 & 0.05 & 0.58 & 0.28 & 0.56 & 0.09 & 0.93 \\
\hline
\end{tabular}

NOTE: The parameterisations differ from the baseline calibration only with respect to the parameters indicated in the rows. The parameter $\rho_{y}$ is the coefficient on the output gap (defined in terms of deviations from the steady state) in the monetary policy rule. Inflation is defined as the quarter-to-quarter growth rate in the aggregate price level. The statistics are computed from logged and HP-filtered series, with $\lambda=1,600$. The variance decompositions are computed by DYNARE using first-order approximations of the model.

The reason for a change in the overall contribution of US shocks is different in each parameterisation. For example, if $\alpha$ (the weight of traded goods in the consumption basket) increases, countries become more open. This implies that foreign demand becomes a larger component of the demand for European output. Analogously, more European consumption demand is spent on foreign goods. As a result, households across the world react more to a change in US prices, and thus Europe's output responds more to US shocks. In further examples, an increase in the contribution of US shocks to the variance of European output also occurs when the home bias parameter, $h$, falls 
(because a lower weight is attached to domestically-produced goods), and when $\gamma_{E}$ falls (because a lower weight is attached to European goods).

Changes in parameter values also affect the relative contribution of each US shock in comparison with the others. For example, if the weight assigned to traded goods, $\alpha$, increases to 0.5 , the contribution of the traded productivity shock to the variance of European output becomes greater than the contribution of any other shock, at least in the floating scenario. This happens because, with $\alpha$ equal to 0.5, the response of European output to a US traded productivity shock is stronger than the response to a non-traded or a demand shock. 57 In further examples, an increase in the relative contribution of the traded productivity shock in comparison with the other shocks can also be observed when $\psi$ increases or $\mu$ falls. On the other hand, the parameters that increase the relative contribution of the demand shocks in comparison with the other shocks are the home bias parameters, $h$, and the size of Europe's economy, $\gamma_{E}$. When these are lower, less is spent on domestic or European goods, and the contribution of US demand shocks to the total variance of European output increases.

By and large, changes in parameter values alter Europe's exposure to each individual shock and to the sum of all US shocks. However, the main results presented in Section 5 are generally robust. Analogously, if Asia kept its exchange rate pegged to the euro, both output and inflation in the United States would respond more to European shocks. Therefore, the transmission of shocks between two countries is dampened when a third country does not peg its exchange rate to one of their currencies.

\section{Conclusions}

One of the consequences of the emergence of the Chinese and several other Asian economies is that their macroeconomic policies, increasingly, will affect the rest of the world. This has been acknowledged implicitly, for example, in the recent academic and policy debate over China's choice of exchange rate regime.

Using a three-country dynamic general equilibrium model that extends the Centre-Periphery model of Corsetti et al (2000), we have analysed how the transmission of US shocks to Europe is affected by the choice of exchange rate regime in a third large country or a bloc of countries, which can be understood either as Asia or China, the largest Asian country.

We have found that, if China pegs its exchange rate vis-à-vis the dollar, both output and inflation in Europe respond more to US shocks. This happens because, in the absence of nominal exchange rate adjustments, China's firms respond to US shocks by implementing significant price changes that strongly affect Europe's relative competitive position. Our general equilibrium model shows that the adjustment of Asian prices initially prevails over the other effects induced by the pegging of the Asian currency. 
It has often been argued that floating exchange rates have the benefit of insulating a country from foreign disturbances. Our results suggest that floating exchange rates have another insulating property: the transmission of shocks between two countries is dampened when a third country does not peg its exchange rate to one of their currencies. This result was obtained in a comprehensive framework, 58 and it has proved to be robust.

Interestingly, our results have also revealed that, despite the increase in the exposure to US shocks, the impact of China's peg against the dollar is likely to have only a modest effect on the overall volatility of Europe's output and inflation. This is because, at least in our calibration, the overall volatility of Europe's output and inflation depends mainly on domestic shocks, and a lot less on US shocks.

Our exercise suggests that if Asia adopts a floating exchange rate regime, the contributions of US shocks to the variance of European output and inflation increase by 56 per cent and 71 per cent in our baseline parameterisation, compared to the hybrid scenario. However, under the baseline and all alternative parameterisations, US shocks explain only a small percentage of the variances of Europe's output and inflation. This result shows up in many open-economy DSGE models. For example, De Walque et al (2005) estimate that US shocks account for only 0.2 per cent of the variance of euro area output, and 1.2 per cent of the variance of euro area inflation. Justiniano and Preston (2010) find that an estimated, structural, small open-economy model generates very little co-movement in international business cycles.

But the exact quantitative impact of China floating would require further extensions. We have aimed to provide a qualitative, rather than quantitative, analysis, and our focus has been limited to the transmission of US shocks. Therefore, we did not assess the relative importance of Asian/Chinese shocks in the European business cycle, and the quantitative impact of Asia's/China's exchange rate regime on the overall volatility of output and inflation in Europe. A successful answer to this distinct question rests, in our view, not only on a fully estimated dynamic macroeconomic model, but also on the availability of reliable time series data for China. Furthermore, we have considered a set-up with full pass-through for ease of analysis and because of the qualitative nature of our investigation. Another extreme assumption - no exchange rate pass-through - would eliminate the direct effect of the choice of exchange rate regime on the competitiveness of China's firms. Empirical studies (for example, Campa and Goldberg (2002)) find that the pass-through in reality lies somewhere in between the two extremes. A precise analysis of the quantitative impact of China's choice of exchange rate regime would thus need to address both of the above extensions. 59

Accepted for publication: 8 December 2010 
APPENDIX

Figure 1: Impulse responses to a positive productivity shock in the US traded sector*
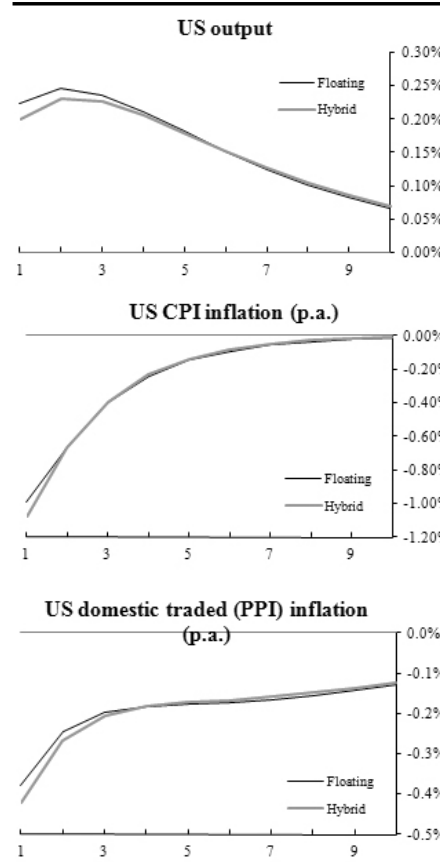

US domestic non-traded inflation

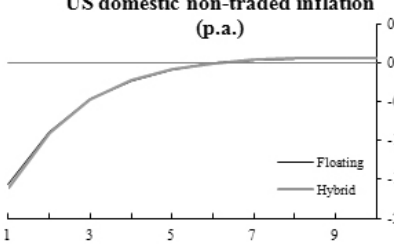

US nominal interest rate (p.a.)
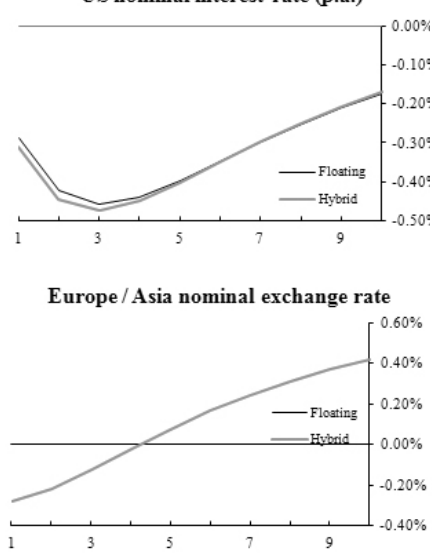

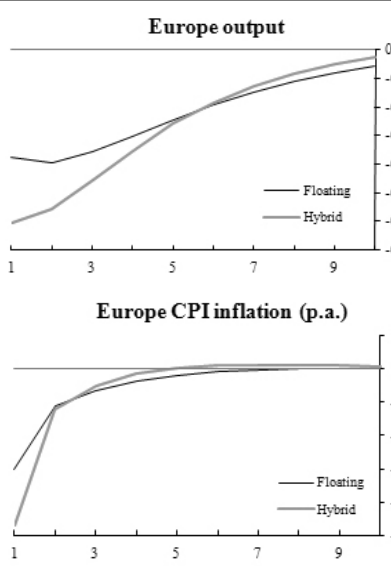

Europe domestic traded (PPI)

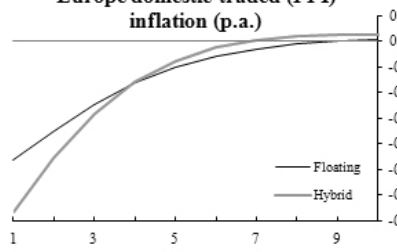

Europe domestic non-traded inflation (p.a.) $0.00 \%$

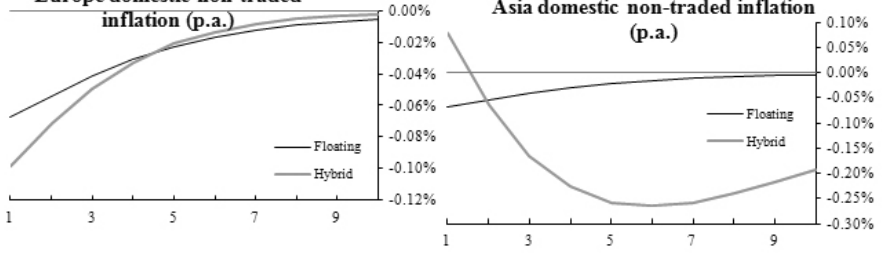

Europe nominal interest rate (p.a.)
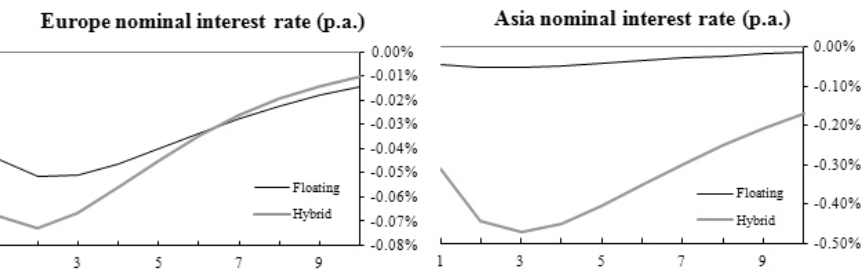

Europe / US nominal exchange rate

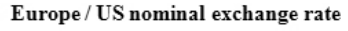

US / Asia nominal exchange rate

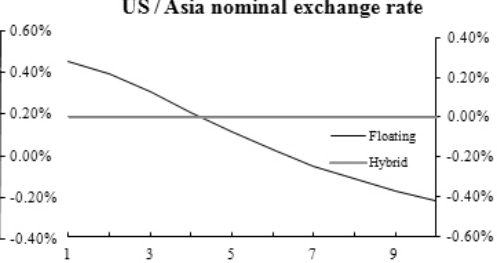



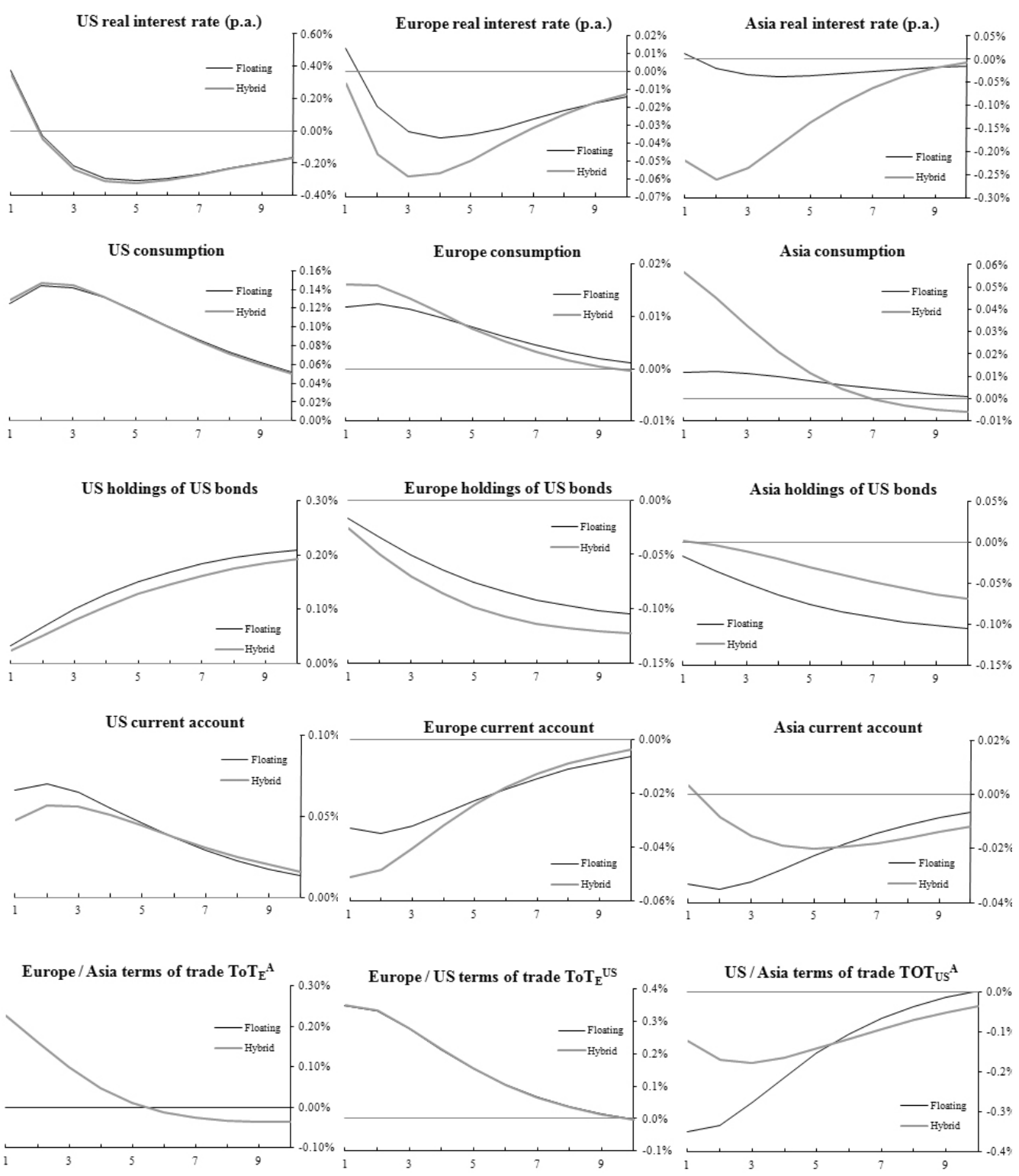

US / Asia terms of trade TOT $_{U S^{A}}$
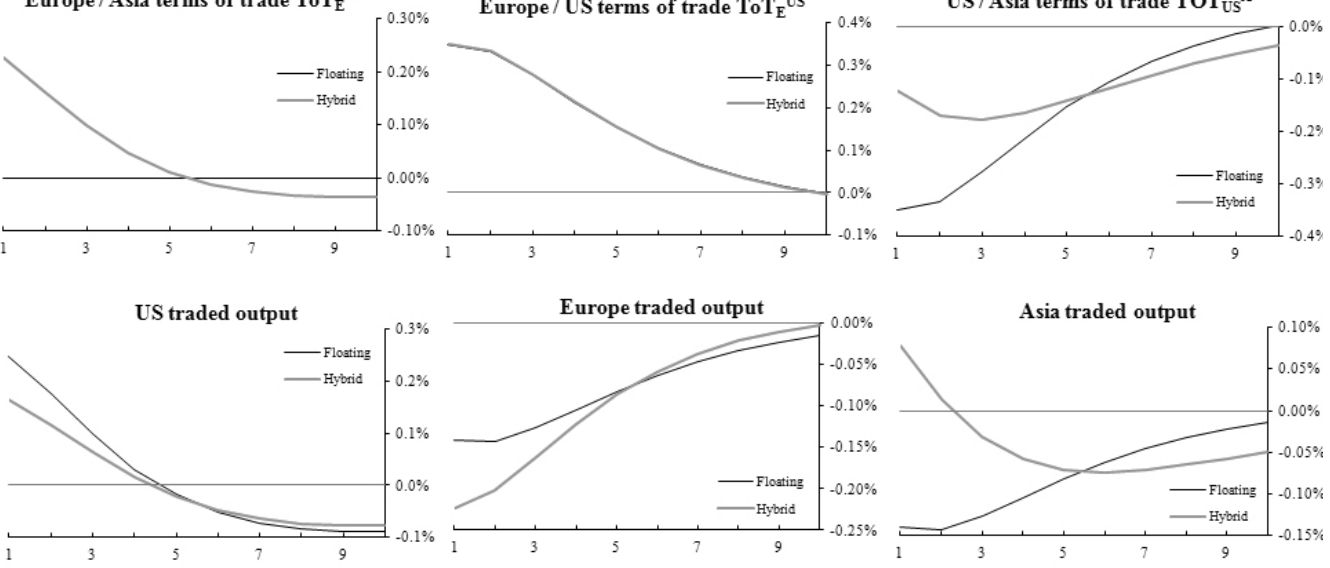


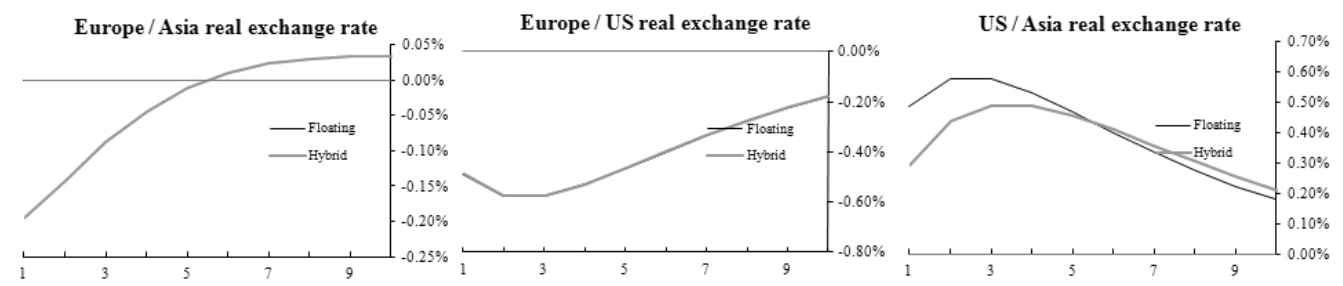

$\mathrm{x}$ Numbers on the horizontal axis are quarters after the shock.

The responses of inflation rates are in percent units. The responses of the current account and bond holdings are percentages of steady-state aggregate consumption. All the remaining impulse responses are percent deviations from the steady state.

Figure 2: Impulse responses to a positive productivity shock in the US non-traded sector*
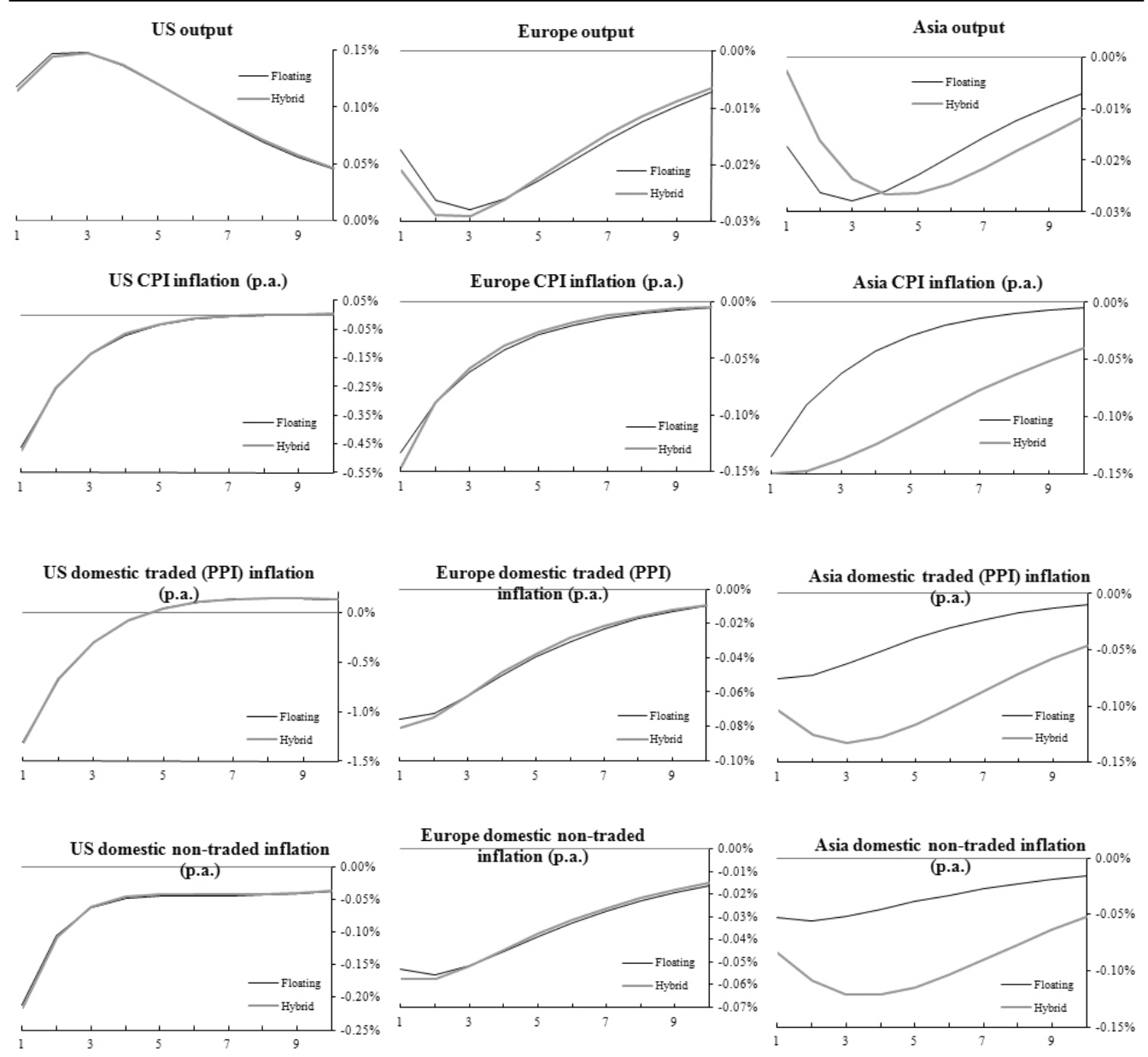

$-27-$ 

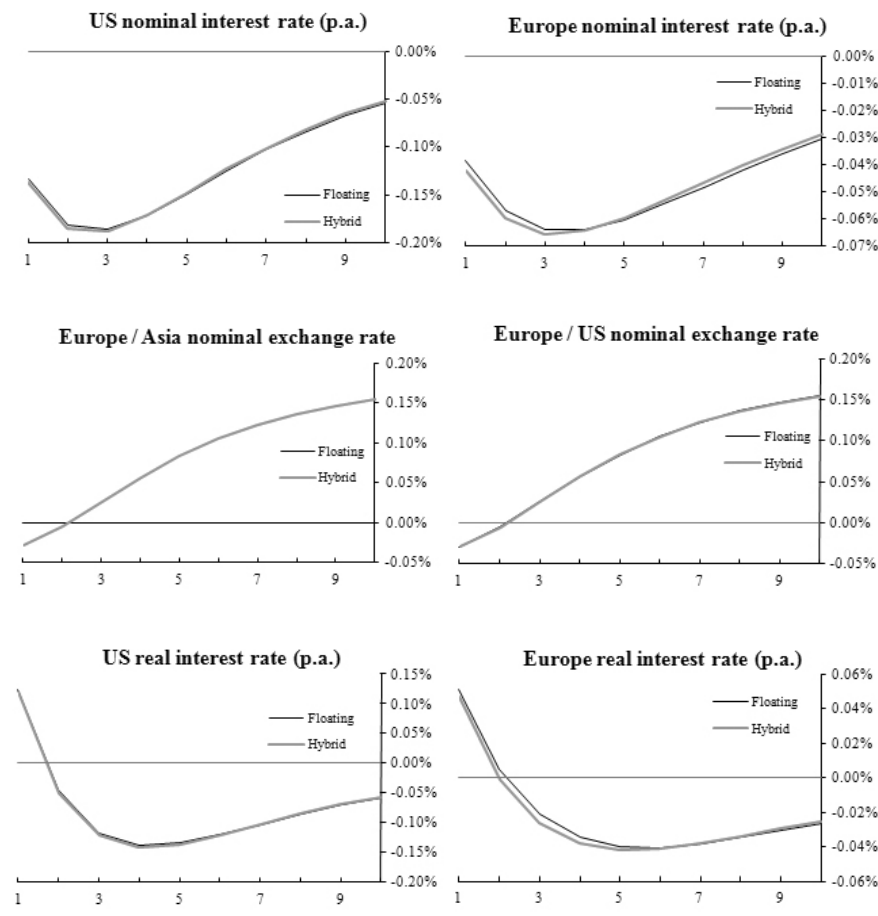

US / Asia nominal exchange rate
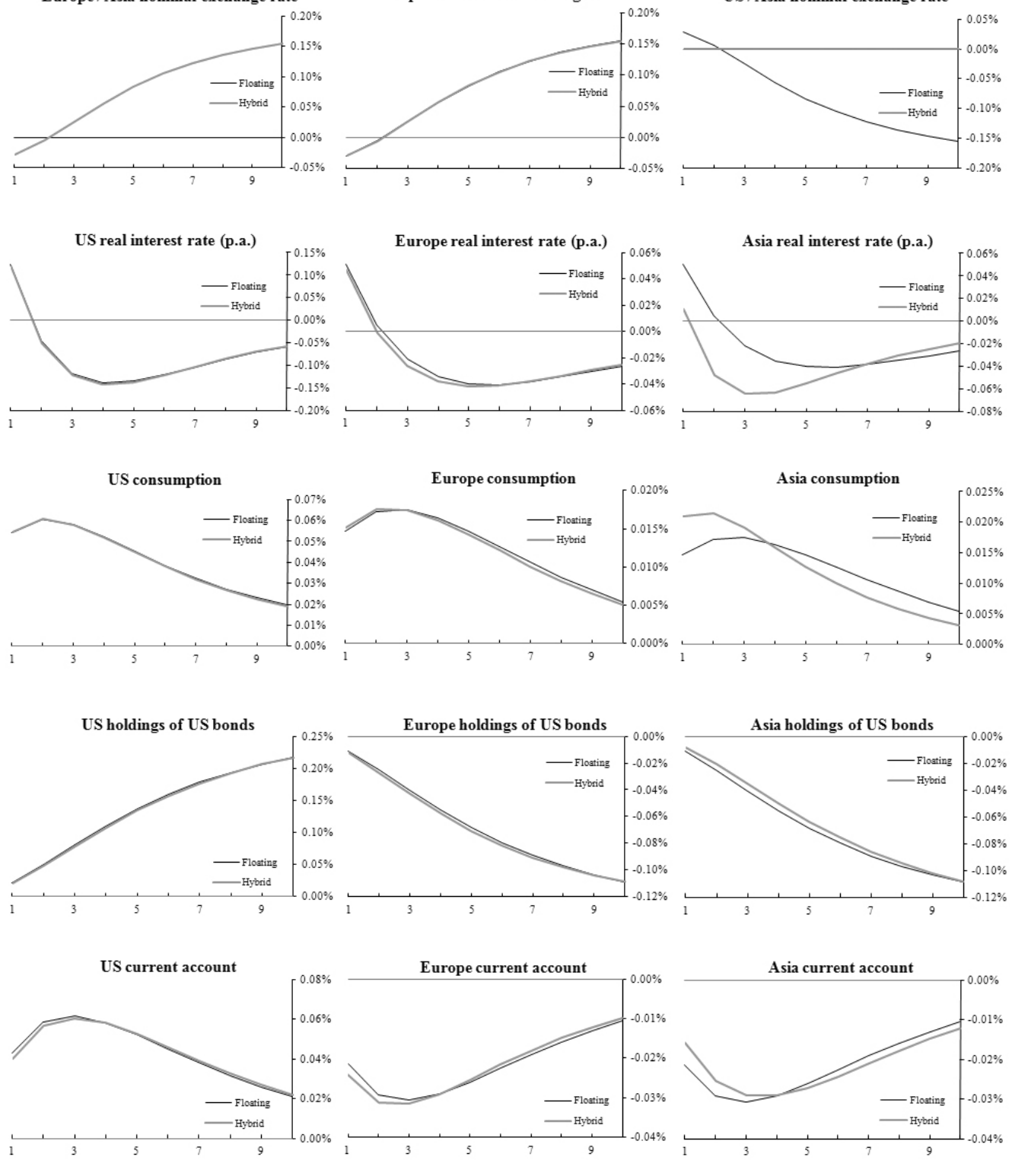

$-28-$

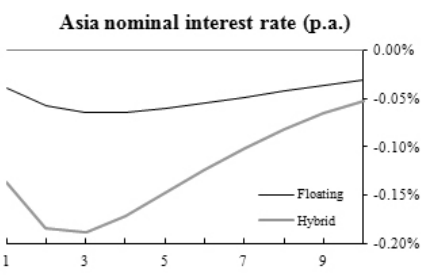

\section{.}

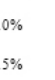

.



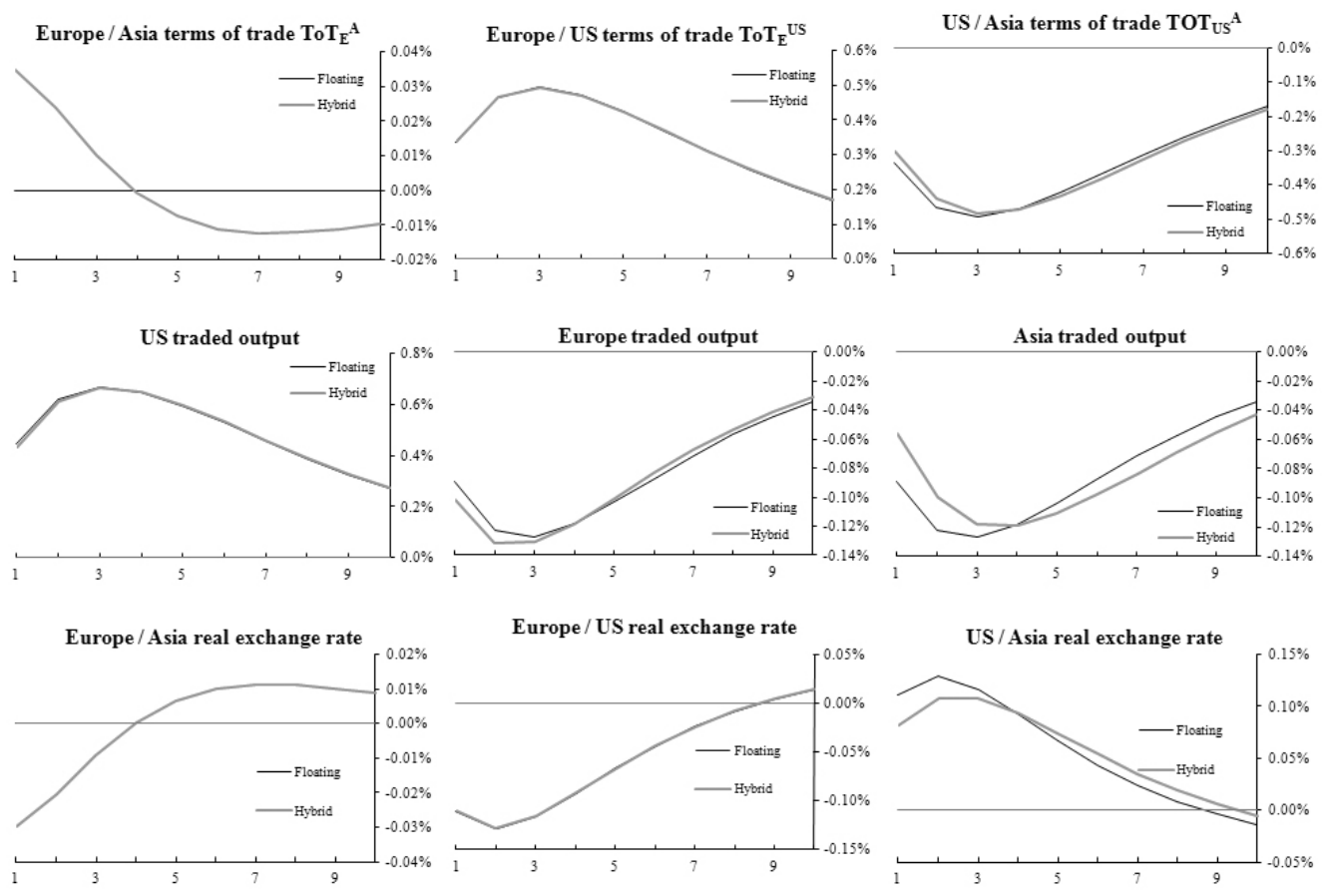

$\mathrm{x}$ see figure 1

Figure 3: Impulse responses to a negative demand shock in the US*
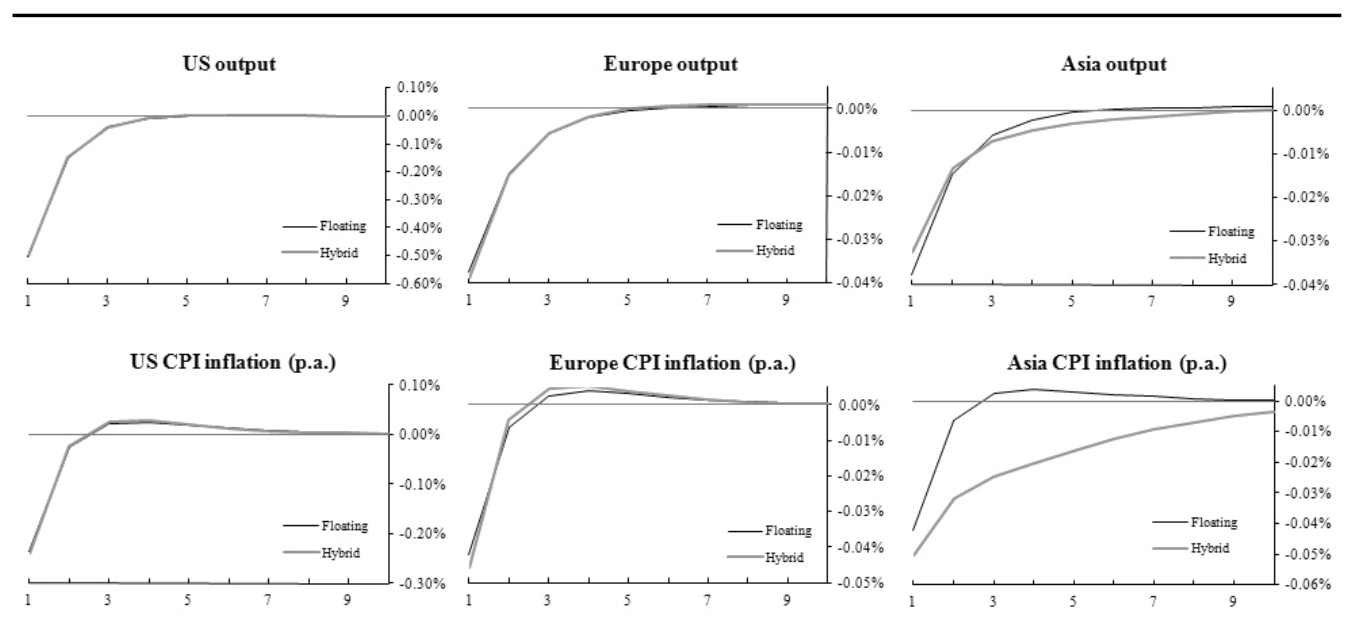

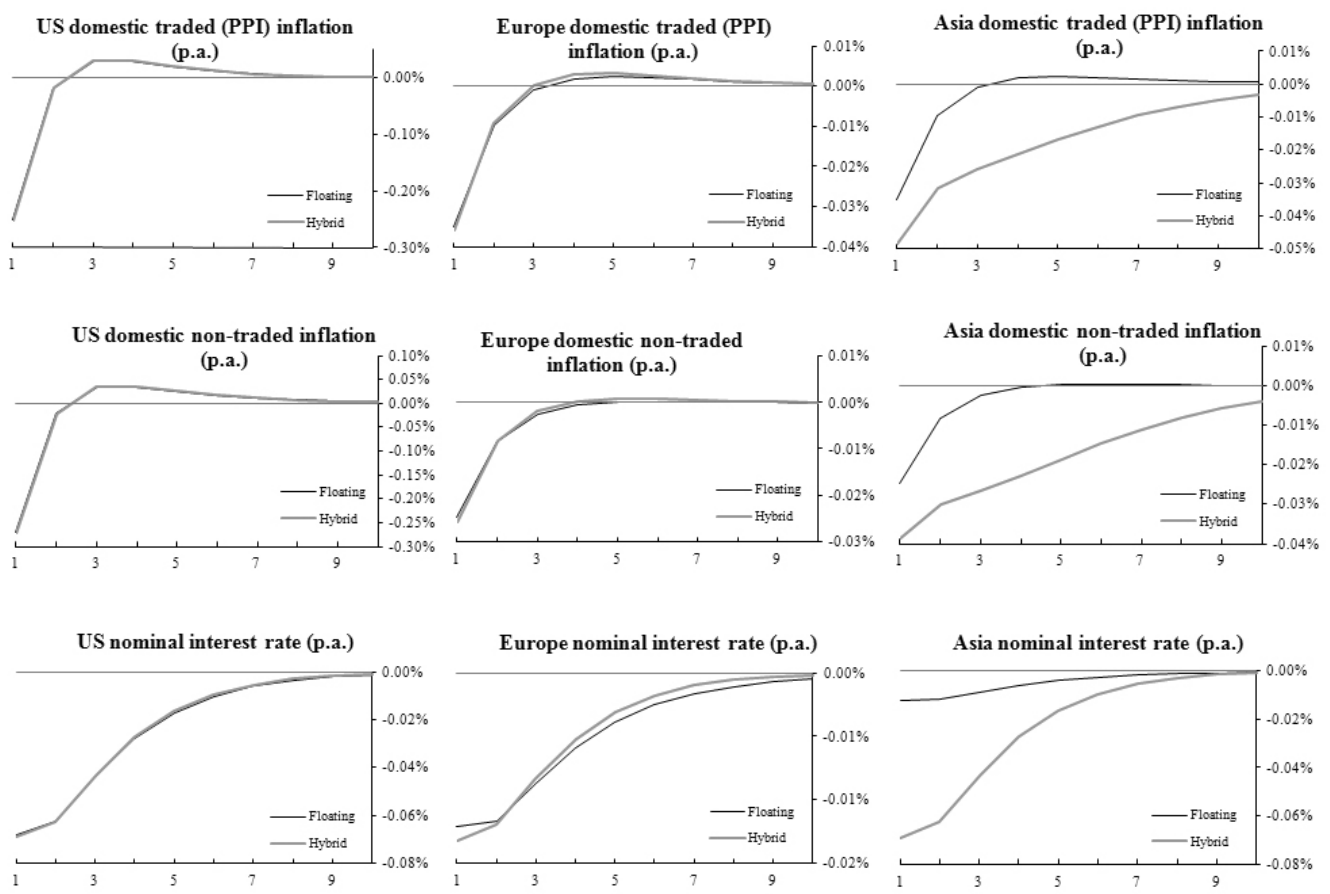

Europe / US nominal exchange rate

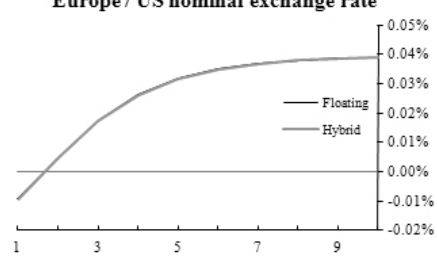

\section{Europe / US nominal exchange rate}

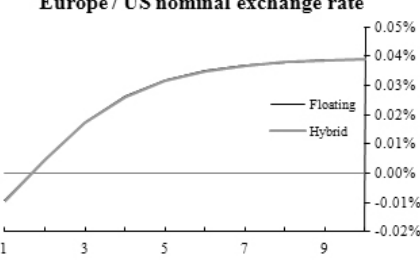

US / Asia nominal exchange rate

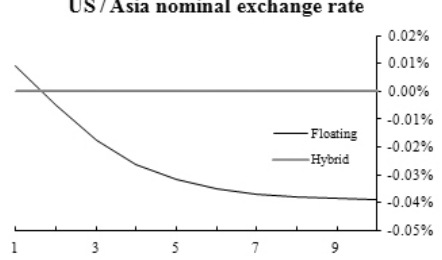

Asia real interest rate (p.a.)
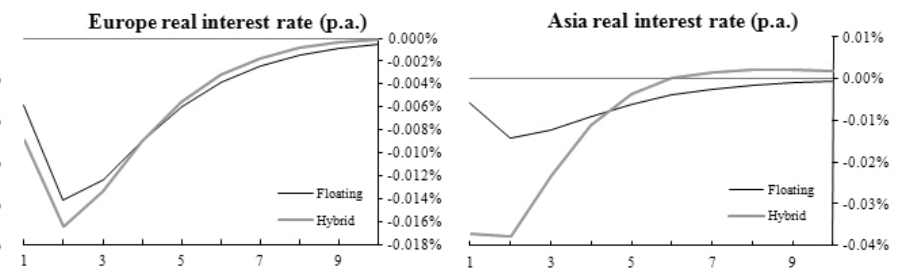

Asia consumption

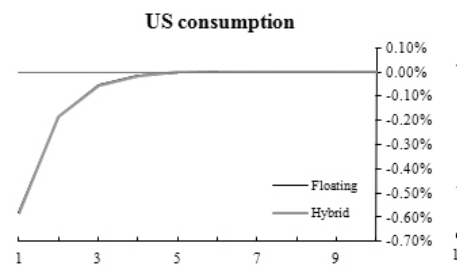

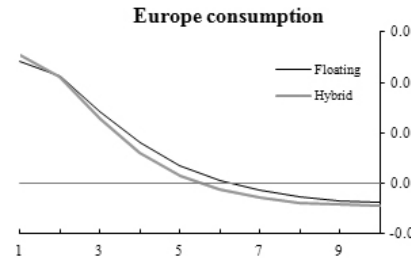

-30 - 
Economic Issues, Vol. 16, Part 2, 2011
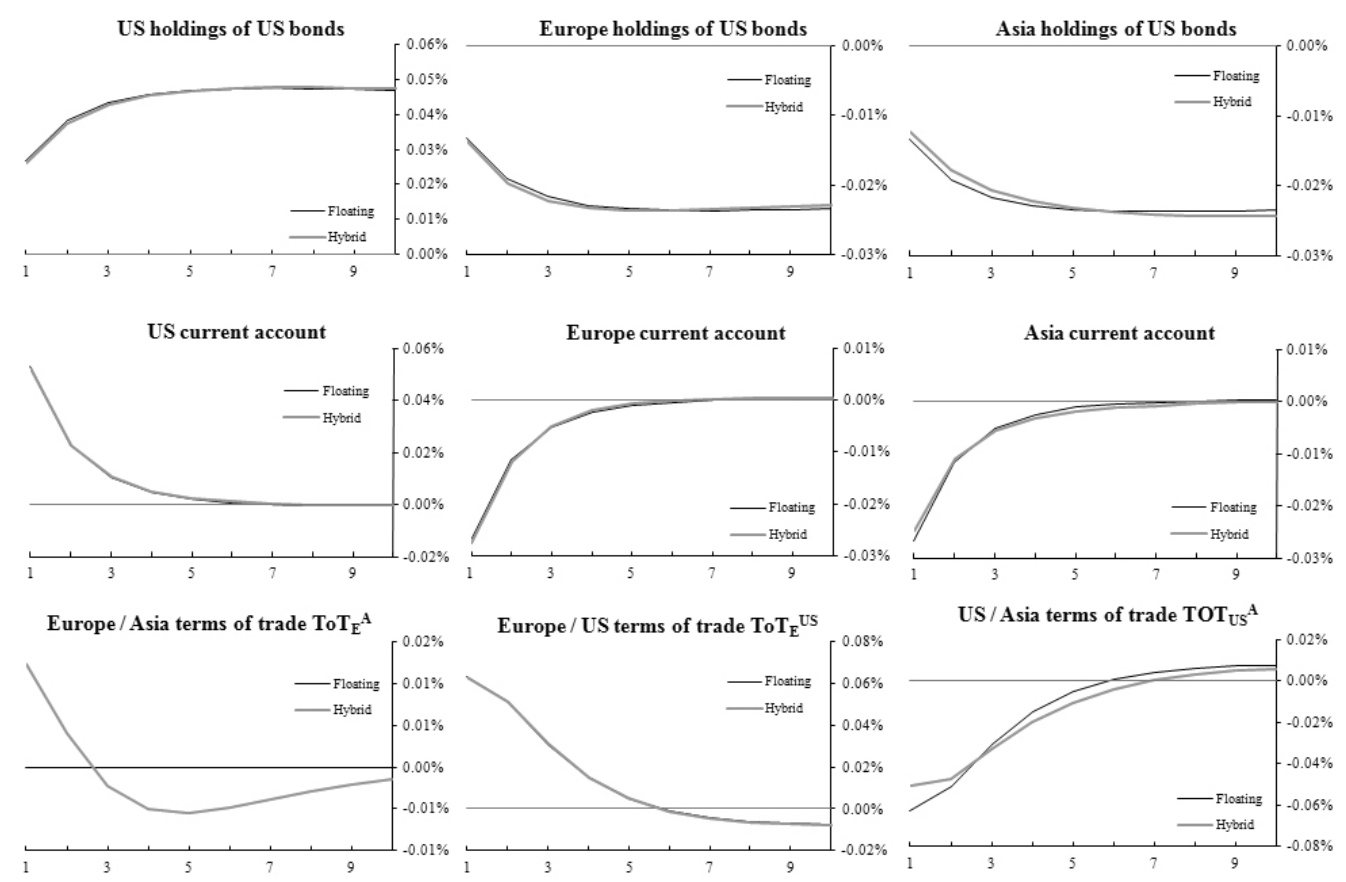

US / Asia terms of trade $\mathrm{TOT}_{\mathrm{US}}$
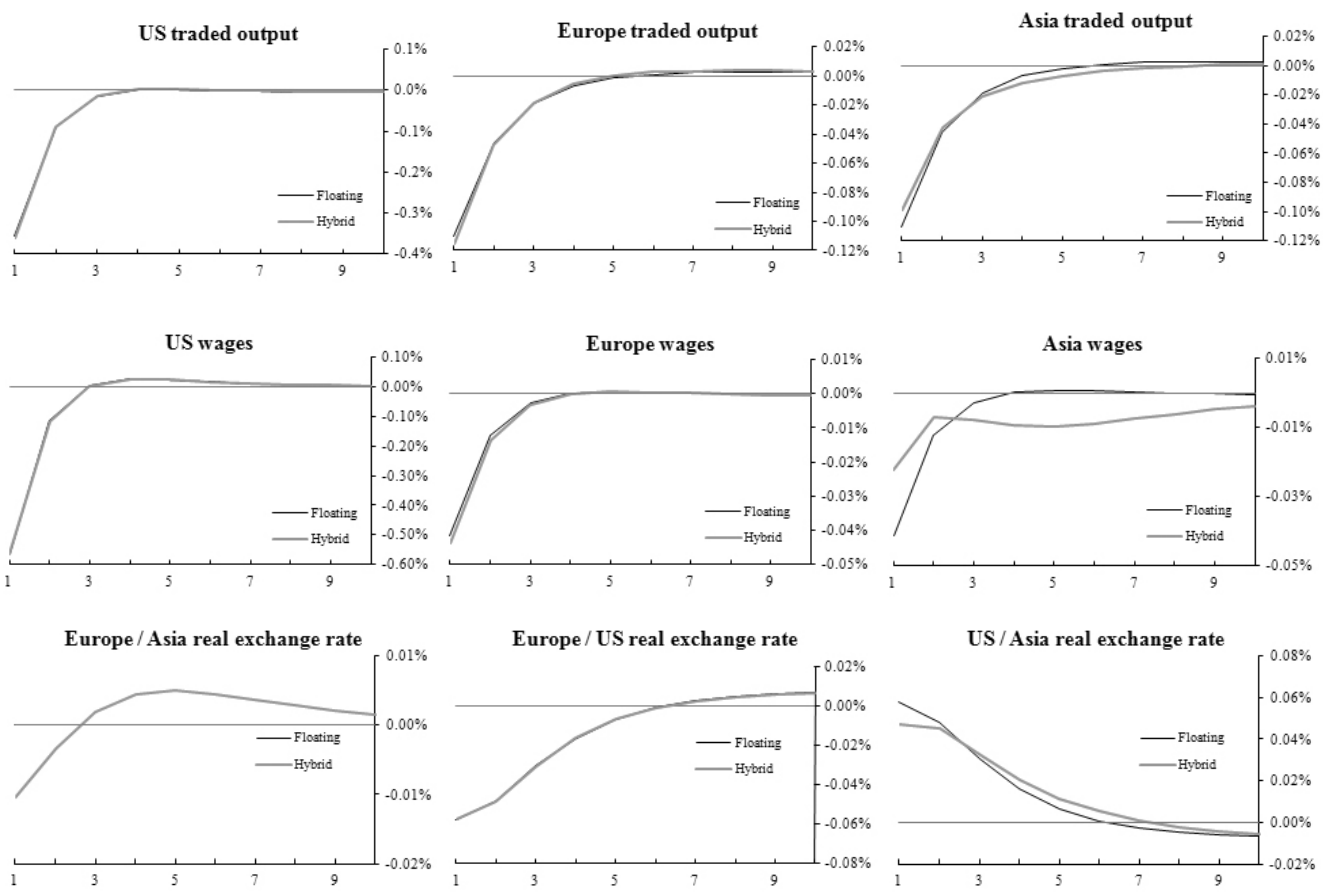

US / Asia real exchange rate

$x$ see figure 1

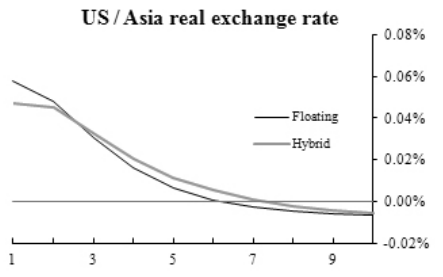




\section{ENDNOTES}

1. National Bank of Serbia, Kralja Petra 12, Belgrade, 11000, Serbia. E-mail: kabinet.monetarno@nbs.rs (Markovic) and Bristol Business School, University of the West of England, Coldharbour Lane, Bristol BS16 1QY (UK). Email: Laura.Povoledo@uwe.ac.uk (Povoledo). This research was carried out while Bojan Markovic was at the Bank of England. The views expressed in this paper are those of the authors, and not necessarily those of the Bank of England or the National Bank of Serbia. We wish to thank Martin Brooke, Michael B Devereux, Karen Dury, Francesco Giavazzi, Peter Howells the participants to the ZEI Summer School, and two anonymous referees for useful comments and Mike Smith for valuable research assistance.

2. Frankel (2009) analyses China's de facto exchange rate regime, and finds that recently China has adopted a basket peg, setting the exchange rate with reference to both the euro and the dollar. In actual fact, the renminbi remained closely linked to the dollar until 2005-06.

3. Mervyn King, 'The International Monetary System', remarks at 'Advancing Enterprise 2005' conference, London. Available at http://www.bankofengland.co.uk/publications/speeches/2005/speech237.pdf.

4. In order to defend a peg to the dollar, Asian central banks have to move their interest rates in line with prevailing interest rates in the United States.

5. Friedman was the first to argue that flexible exchange rates insulate a country from foreign shocks.

6. Additionally, Faruqee et al (2005) find that the response of Japan's and the euro area's output to a sudden loss in appetite for US assets is more pronounced if emerging Asia adopts a flexible exchange rate regime.

7. The explicit modelling of the tradeable and nontradeable sectors has often been done solely in order to explain certain features of the aggregate economy (for example, the observed deviations from purchasing power parity). In our model, this differentiation is very significant because the increase in Europe's exposure to US shocks is consistently more marked in the case of non-traded productivity shocks.

8. The countries are named only for expositional purposes. Further details are available in the calibration section.

9. The size of a sector is the measure of goods produced, or firms operating, in that sector.

10. Thus, we do not consider the case of local currency pricing. The price of any country's traded good is identical in all countries (the law of one price holds), but the nontraded goods sector and the home bias in preferences imply that purchasing power parity does not hold.

11. Restricting the number of shocks certainly facilitates the analysis, but it may be at the expense of realism. For this reason we decide to keep a limited but sufficiently 'representative' menu of shocks, by assuming that uncertainty can originate either from the supply or the demand side of the economy. 
12. Neiss and Nelson have demonstrated that this disturbance to consumption preferences is the equivalent of a 'real demand' or 'IS' shock. When a negative demand shock occurs, the attractiveness of consumption with respect to leisure decreases.

13. The set of firms operating in the traded (non-traded) goods sector in country $j$ is denoted with $S_{T}^{j}\left(S_{N}^{j}\right)$. The variables $z_{T}^{j}$ and $z_{N}^{j}$ are indices for firms.

14. Our model allows for a non-zero exogenous steady-state holding of bonds. Therefore, this is a cost of holding a volume of bonds different to the steady state volume. But, as the bond portfolio choice is exogenous, in order to keep the model parsimonious, we assume that bond holdings are zero in the steady state.

15. This point has been demonstrated by Schmitt-Grohe and Uribe (2003).

16. Households pay the cost of holding bonds to financial intermediaries located in their own country, and firms pay the cost of adjusting their prices to the issuers of new 'menus'. We assume that financial intermediaries and the issuers of menus are located in each one of the three countries and are owned by households; therefore, we add to the budget constraint an all-inclusive lump-sum rebate or rent $R^{j}$

17. Therefore, the degree of substitutability between European and US goods, $\psi$, can be different from the degree of substitutability between Asia's goods and the bundle formed by European and US goods, $\rho$.

18. The assumption that the traded goods produced by Europe and the United States form a distinct consumption bundle, separate from Asian goods, is made in order to check whether our results can be altered by a higher elasticity of substitution in consumption between European and US goods, which could be justified by the similarity of the industrial structure ('new' goods in both Europe and the US, 'mature' goods in Asia).

19. As observed by Prescott (1986): 'the capital stock varies little cyclically and is nearly uncorrelated with output'. A common assumption in the new open economy literature is constant marginal labour productivity and constant returns to scale, but the assumption of imperfect competition also makes it possible to allow for decreasing marginal labour productivity.

20. Our specification of the adjustment cost function is close to Ireland (2001), except for the absence of a component that depends on the change in the firm's inflation rate. We have chosen to neglect that component because Ireland's estimates indicate that the data prefer the specification in which adjustment costs apply only to changes in the price level, but not to changes in the inflation rate.

21. We have chosen this functional form so as to reproduce a standard linear feedback rule (with smooth interest rate adjustment) in both a linear and a log-linear approximated solution of the model.

22. A 'hat' denotes a percentage deviation relative to the steady state.

23. For example, in terms of population China is approximately 4 times as large as either Europe or the United States, but only 0.14 times as large in terms of GDP.

24. Since the possibility of modelling the substitutability between European and US goods separately from the substitutability of Asian goods is missing in Obstfeld and Rogoff's three-country model, we set $\psi$ equal to $\rho$ in our benchmark. 
25. Obstfeld and Rogoff (2005) assume that US, European and Asian households attach a weight of 0.7 to their own domestic products. Moreover, Europe and the US place a weight of 0.1 on each other's traded goods and a weight of 0.2 on Asian goods. On the other hand, Asia places a weight of 0.15 on both Europe and US' traded goods.

26. Our choice of $\phi$ implies a steady state mark-up of prices over marginal costs of approximately 14 per cent.

27. See 'Globalization and External Imbalances', Chapter 3, World Economic Outlook, International Monetary Fund, April 2005.

28. (C) 2006 Wolfram Research, Inc.

29. Details on solving non-linear models using DYNARE can be found, for example, in Juillard (2001).

30. One could think of a third scenario where Asia pegs to a basket of currencies that include both dollar and euro with equal weights - the Basket scenario. This scenario is simply an average of the two examined scenarios.

31. Thus for each country we construct a unique measure of the real interest rate, obtained from the nominal rate on the domestically-issued bond.

32. The only situation when this rule does not hold is when country $j$ is hit by a demand shock.

33. Impulse responses are presented in Figure 1.

34. The impulse responses of wages and all the other variables after the shocks are available from the authors on request.

35. There are, however, very short-lived initial increases in Europe and Asia's real interest rates, because of falling inflation rates.

36. As the maximisation problem of the firm illustrates for the special case of traded goods, the factors that affect output demand are the relative prices and the domestic and foreign consumption of European goods.

37. In our set-up, the level of output affects marginal costs in two ways. First, the marginal productivity of labour is decreasing in output. Secondly, higher output itself implies higher labour demand, and therefore higher wages.

38. Responses are shown only for holdings of US bonds. The responses of Asian and European bonds are almost identical.

39. Impulse responses are presented in Figure 2.

40. This is because the nominal interest rate reaction in the United States is stronger under the non-traded productivity shock than under the traded productivity shock.

41. By comparing Figure 1 with 2, we can notice that the two US bilateral real exchange rates appreciate more after a nontraded productivity shock than after a traded productivity shock, which contradicts somewhat the Balassa-Samuelson effect. This happens because of the relative weight assigned to the non-traded sector in our calibration. We are grateful to an anonymous referee for drawing our attention to this point. 
42. European traded output falls because worldwide demand gradually switches to the relatively cheaper US traded goods. Moreover, the fall in US traded prices causes a fall in the aggregate traded price index. As a result, European households consume fewer non-traded goods, and European non-traded output falls, too.

43. Impulse responses are presented in Figure 3.

44. If Asian prices did not fall then Asian firms would experience large output losses, because of the competition from cheaper US goods and the fixed exchange rate. But falling output would also imply lower current and expected future marginal costs, which in the end would induce Asian firms to cut their prices. In practice, this self-correcting mechanism ensures that the US/Asia terms of trade does not fall severely.

45. And since both Asian traded and non-traded goods prices fall, there is neither a dramatic fall in the US/Asia terms of trade, nor a dramatic change in the relative price of Asian non-traded goods.

46. Allowing Asian firms to discriminate between export markets and set a different price for sales at home and abroad is unlikely to affect our main result. This is because Asian firms face competition from cheaper US traded goods not only in their domestic market, but also in the European and US markets. The same happens with Europe's and US's firms. Fairly general assumptions ensure that, even in the presence of decreasing marginal productivity, the destination of output does not affect marginal costs significantly.

47. With no exchange rate pass-through on import prices, the choice of exchange rate regime does not affect directly the competitiveness of Asian firms vis-à-vis firms in the United States. We regard this as an extreme or limiting case, as is our assumption of a full pass-through. Empirical studies (Campa and Goldberg (2002), for example) find that the pass-through in reality lies somewhere in between the two extremes. In all the intermediate cases of incomplete pass-through, Asia's competitiveness would be directly affected (perhaps more moderately) by the choice of exchange rate regime and the response of Asian prices would still be different in the two scenarios.

48. If they were quantitatively more important, they would actually cause European output to fall less, not more, under the hybrid than under the floating scenario. This is because, on its own, the depreciation of the euro vis-à-vis the Asian currency actually increases the competitiveness of European traded goods. On the other hand, interest rate changes have implications for the transmission through the asset market. But the asset market changes significantly the transmission under the hybrid scenario only in the case of non-traded productivity shocks, but in that case European consumption (and therefore the domestic demand for output) actually increases more under the hybrid scenario.

49. The model of Chari et al (2002) generates real exchange rates that are as volatile as in the data. Their result is, however, influenced by their assumption that prices are set in the local, rather than the producer's, currency.

50. We do not aim to measure precisely the quantitative impact of Asia's choice of exchange rate regime on the total volatility of output and inflation in Europe. The major focus of our analysis is on qualitative rather than quantitative issues. 
51. By looking at impulse responses in the appendices we can also infer that the responses of European output and inflation to shocks originating in Europe are larger in magnitude than the responses of the same variables to US shocks. This explains why US shocks account only for a small percentage of the variances of Europe's output and inflation.

52. Since our aim is a qualitative, rather than quantitative, analysis, we do not perform a full econometric estimation of our model.

53. All impulse responses obtained under alternative parameterisations are available from the authors on request.

54. For the sake of conciseness, we do not include in Table 4 the case of changes in $\xi_{C}$ as the results are not particularly interesting.

55. There are very few parameterisations (namely absence of home bias) where, after a traded US shock, European output falls less in the hybrid than in the floating scenario. But since this does not happen with the other two shocks, the general result that Europe's exposure to US shocks is higher in the hybrid scenario is also confirmed in these cases.

56. In almost all the alternative parameterisations, the transmission and the amplification under the hybrid scenario of each individual shock are as described in Section 4. There are only a few exceptions that are quantitatively insignificant. Therefore, our three main results will also be robust to several changes in more than one parameter at a time.

57. Interestingly, this is not necessarily the case in the hybrid scenario, since again the non-traded productivity shock is the most important contributor to output volatility.

58. We can say this comprehensive framework, in itself, encompasses several smaller models.

59. Another important aspect that ought to be considered in a quantitative investigation is the degree of capital mobility, which varies among the countries in the Asian or fixed exchange rate block. A rough indication is provided by the correlation coefficient between US and Asian interest rates. For example, the correlation between the US Dollar 3 month LIBOR and the Chinese 3 month CHIBOR is 0.30 , whilst the correlation between the same US rate and the Hong Kong Dollar 3 month HIBOR is 0.74 (calculations obtained from Reuters 3000 Xtra, using daily data). However, given that ours is a theoretical investigation, 'Asia' may well be any group of countries having some sort of fixed exchange rate vis-à-vis the dollar, such as some Latin American economies, as well as the Gulf countries. We are grateful to an anonymous referee for drawing our attention to this point.

\section{REFERENCES}

Artis M, Osborn D R and Perez P J (2006) 'The International Business Cycle in a Changing World: Volatility and the Propagation of Shocks in the G7', Open Economies Review, 17, 255-279. 
Benigno P (2009) 'Price Stability with Imperfect Financial Integration', Journal of Money, Credit and Banking, 41, 121-149.

Benigno G and Thoenissen C (2003) 'Equilibrium Exchange Rates and UK Supply Side Performance', Economic Journal, 113, 103-124.

Chari V V, Kehoe P J and McGrattan E R (2002) 'Can Sticky Price Models Generate Volatile and Persistent Real Exchange Rates?', Review of Economic Studies, 69, 533563.

Corsetti G, Pesenti P, Roubini N and Tille C (2000) 'Competitive Devaluations: A Welfare Based Approach', Journal of International Economics, 51, 217-241.

De Walque G, Smets F and Wouters R (2005) 'An Estimated Two-Country DSGE Model for the Euro Area and the US Economy', paper presented at the 'Workshop on Commodity Prices' at the Bank of Canada, July 2006, http://www.bankofcanada.ca/en/conference_papers/commodity_price2006/papers.html

Fagan G, Henry J and Mestre R (2005) 'An area-wide model (AWM) for the euro area', Economic Modelling, 22, 39-59.

Faruqee H, Laxton D, Muir D and Pesenti P (2005) 'Smooth Landing or Crash? ModelBased Scenarios of Global Current Account Rebalancing', Proceedings, Board of Governors of the Federal Reserve System.

Frankel J A (2009) 'New Estimation of China's Exchange Rate Regime', Pacific Economic Review, 14, 346-360.

Friedman M (1953) 'The Case for Flexible Exchange Rate' in Friedman M (ed) Essays in Positive Economics, Chicago: University of Chicago Press.

Gali J, Gertler M and Lopez-Salido J D (2007) 'Markups, Gaps, and the Welfare Costs of Business Fluctuations', Review of Economics and Statistics, 89, 44-59.

Ghironi F and Melitz M (2005) 'International Trade and Macroeconomic Dynamics with Heterogeneous Agents', The Quarterly Journal of Economics, 120, 865-915.

International Monetary Fund (2005) 'Globalization and External Imbalances', World Economic Outlook, Chapter 3, April, 109-156.

Ireland P N (2001) 'Sticky-price models of the business cycle: Specification and stability', Journal of Monetary Economics, 47, 3-18.

Juillard M (2001) 'DYNARE: A program for the simulation of rational expectation models', Computing in Economics and Finance, 213.

Justiniano A and Preston B (2010) 'Can structural small open-economy models account for the influence of foreign disturbances?', Journal of International Economics, $81,61-74$.

King M (2005) 'The International Monetary System', remarks at 'Advancing Enterprise 2005' conference, London. http://www.bankofengland.co.uk/publications/speeches/2005/speech237.pdf

Neiss K S and Nelson E (2003) 'The Real-Interest-Rate Gap as an Inflation Indicator', Macroeconomic Dynamics, 7, 239-262. 
Prescott E C (1986) 'Theory Ahead of Business-Cycle Measurement', CarnegieRochester Conference Series on Public Policy, 25, 11-44.

Obstfeld M and Rogoff K S (1995) 'Exchange Rate Dynamics Redux', Journal of Political Economy, 103, 624-660.

Obstfeld M and Rogoff K S (2005) 'Global Current Account Imbalances and Exchange Rate Adjustments', Brookings Papers on Economic Activity, Issue 1, 67-123.

Rotemberg J J and Woodford M (1998) 'An Optimization-Based Econometric Framework for the Evaluation of Monetary Policy: Expanded Version', NBER Technical Working Papers 233.

Rotemberg J J and Woodford M (1999) 'The Cyclical Behavior of Prices and Costs' in Taylor J B and Woodford M (eds), Handbook of Macroeconomics, vol. 1B, 1051-1135, Amsterdam: Elsevier/North-Holland.

Schmitt-Grohe S and Uribe M (2003) 'Closing Small Open Economy Models', Journal of International Economics, 61, 163-185.

Spange M and Zabczyk P (2006) 'Sterling Implications of a US Current Account Reversal', Bank of England Working Paper 296. 